No $2005-23$

December

\title{
World Trade Competitiveness: A Disaggregated View by Shift-Share Analysis
}

Angela Cheptea Guillaume Gaulier Soledad Zignago 


\section{World Trade Competitiveness: A Disaggregated View by Shift-Share Analysis}

No $2005-23$ December

Angela Cheptea Guillaume Gaulier Soledad Zignago 


\section{Table of Contents}

$\begin{array}{lr}\text { 1. Introduction } & 10\end{array}$

2. A Descriptive Analysis of World Trade $\quad 11$

3. A Renewed Shift-Share Methodology Applied to Exports' Growth 15

4. Decomposition of Exports' Market Share Growth 18

5. Beyond Trade Performance: Explaining the Results 25

5.1. A look at the data by clustering . . . . . . . . . . . . . . . . 25

5.2. Explaining Export Performance . . . . . . . . . . . . . . . 26

$\begin{array}{lr}\text { 6. Conclusion } & 29\end{array}$

$\begin{array}{ll}\text { A Trade data } & 32\end{array}$

B Detailed Results $\quad 32$ 
World Trade Competitiveness: A Disaggregated View By Shift-Share ANALYSIS

\section{SUMMARY}

The period from 1995 to 2002 was marked by a slight slowdown in the growth of world trade: Expressed in volume terms, annual growth stood at 5.9\% for 1995-2002, compared to $6.2 \%$ for the previous decade. In these conditions the strength of exports from the "South" was remarkable: their annual average growth stood at $9.4 \%$, leading to a rise in the share of the world market of 5.3 percentage points. Leaving aside this overall trend, the performances of different countries, from the "North" as well as from the "South", are very heterogeneous. The aim of this study is to disentangle competitiveness and structural factors, geographic and sectoral specialisation patterns, that drove the exports growth of world countries for the period 1995-2002. Bilateral trade flows between the largest 88 countries, including intra-EU trade, are considered in the analysis.

The gains or losses of world market shares by individual countries are often considered as an index of their trade competitiveness. But given changes in demand, the relative medium-term inertia of geographical and sectoral specializations affect such outcomes. It is therefore interesting, to be able to distinguish the impact of a country's initial position in different markets relative to its capacity to adapt and to its competitiveness. We develop a quantitative methodology for breaking down the volume growth in trade for each country into three components: a geographic structure effect, a sectoral effect and a performance effect. Countries have no influence on the structural effects, which result from the growth in the markets to which they export, given their original geographical and sectoral specialisation. In contrast, the performance effect indicates the degree to which the exporting country was able to gain (or lose) market shares. This performance effect can be partially attributed to the capacity of the country to adapt its sectoral and geographical specialisations. We refer then to the residual component of performance effect, which includes price and non price competitiveness, as "competitiveness".

The method used is similar to a shift-share analysis, but has the advantage of being independent of the structural breakdown with respect to the order in which the geographic and sectoral dimensions are taken into account. Furthermore, it allows the significance of the effects measured to be assessed.

The geographic structural effects depend on proximity factors and partner countries demand, both components being out of control of the exporting country. As a result, all countries in East and South-East Asia, beginning with China, experienced a negative geographical demand effect due to the regional consequences of the 1997-98 financial crisis and the chronic weakness of Japanese demand. Similarly, given the weakness of import demand, the dependency with respect to European outlets was a major handicap for countries in the Europe-Africa region. As for North American countries, they benefited from the intensification of regional trade within the NAFTA.

The sectoral pattern of growth in import demand has favoured only a small number of countries. During this period, world trade growth was driven by investment in information and communication technologies and by household consumption in the United States. Sectors like cars, chemicals and pharmaceuticals, electronics, telecommunications equipment, as well as computers and transport equipment benefited from stronger demand. In contrast, food and agriculture, together with other basic industries (metals, paper, leather etc.) have experienced relatively weak demand. In the textile and clothing sectors, the "South" has already acquired a major share of 
Northern markets, so these sectors are less marked by increasing export markets than by a redistribution of market shares among exporters. These patterns changed however during the last two years, given the spectacular increase in energy and primary goods prices. The latter two effects being attributed to the expanding Chinese demand, the trend reversal is likely to persist over the following years.

Overall, past sectoral trends have favoured Northern countries and have handicapped Southern countries specialised in low technology consumer goods. Among developed countries, Singapore, Ireland and Japan were the most favoured by their sectoral trade specialisations. In contrast, New Zealand, Australia and Greece, which are largely specialised in food and agriculture (F\&A), along with Portugal specialised in F\&A and textiles, all recorded negative sectoral effects. However, Greece and Ireland have shown the best performance during the period in terms of adapting exports to the changing sectoral demand.

In the "South", the sectoral effect was positive only for Malaysia, Mexico, Philippines, and Slovenia. The latter three also experienced positive sectoral adaptation. South-East Asian countries, including China, and most transition countries, including Russia, encountered relatively small negative sectoral effects which they overcame through a proper adaptation. The dynamic behaviour of markets increases the importance of the successful capacity to adapt, though making the latter difficult to maintain over time.

At the start of the period, imports by the "North" (especially by the United States) were very dynamic. Given their scale, they accounted for $87 \%$ of the growth in world imports and so "pulled along" Southern exports. During the next three years, the slowing down of imports by the "North" did not stop the "South" 's exports from developing. What is remarkable during this period is that the "South" was no longer just a supplier for the "North", but its imports too expanded very strongly, as their contribution to international trade growth almost tripled.

Grouping the countries into large zones shows that the increased market shares of the "South" have mainly come from the Central and East European Countries along with Turkey on one hand, and the emerging Asian countries on the other hand. These gains are mainly explained by the competitiveness of these countries, which largely compensates disadvantages linked to their sectoral specialisation. In Latin America, the improvement in competitiveness just offsets the major handicap in sectoral specialisation, but does not allow most of the countries to maintain their world market share. African and the Middle East countries accumulate both unfavourable sectoral (especially for African countries) and geographic specialisations, as well as a poor adaptation to the markets' dynamics. African countries have the lowest competitiveness of exports as a group.

The EU recorded the best performance in the "North", compared to the United States and Japan. Partially this result is driven by the good positioning of EU member countries on the European market. Confronted with the emergence of Southern exporters, European competitiveness permitted the Union to maintain more or less its market shares. On the contrary, competitiveness losses by the US and Japan are significant and of about the same magnitude. For both countries, however, such sluggish competitiveness was compensated by other factors: the geographical advantages for the US and the sectoral advantages for Japan. Overall, Japan and Singapore along with most African countries recorded the largest fall in market share. 


\begin{abstract}
We develop an improved shift-share methodology and employ it to estimate the trade competitiveness of 88 world countries during the 1995-2002 period and to identify factors that drove each country's increase or drop in exports market share. Along with the export competitiveness, we consider the geographical and sectoral dimension of countries' initial position on different import markets and of their capacity to adapt to shifts in the world economy. Differently from the traditional method employed in the literature, our procedure yields identical results regardless the order in which trade is decomposed in geographical and sectoral factors. Moreover, it produces standard errors and permits to evaluate the statistical significance of each effect.

During this period, the strong demand for elaborated products has benefited the developed countries and disadvantaged most of the South, especially the least-performing countries. Despite the unfavorable sectoral breakdown of the global import demand, exporters from the South recorded remarkable gains in market share over the 1995-2002 period. The emergence of the South, not just as a supplier of the North but as well as a rapidly expanding market, was mainly driven by Central and East European countries along with Turkey on one hand, and emerging Asian countries on the other hand. These gains are mainly explained by the competitiveness of their exports, which largely compensated for disadvantages linked to their sectoral specialisation. In Latin America, the improvement in competitiveness just offsets the major handicap in sectoral specialisation, without allowing most of the countries to maintain their market share. African and the Middle East countries accumulate both unfavourable sectoral and geographic specialisations, as well as a poor adaptation to the markets' dynamics.

The EU recorded the best performance in the North by maintaining its market share, especially on the domestic market, regardless the emergence of Southern exporters. On the contrary, competitiveness and market share losses by the US and Japan are significant and of similar magnitude. Japanese exports have suffered from the general weakening of the domestic economy, while the high level of the dollar in the beginning of the period has reduced the competitiveness of American products. For both countries, however, such sluggish competitiveness was slightly compensated by other factors: geographical advantages for the US and sectoral advantages for Japan.
\end{abstract}

JEL classification: F12, F15

Key words: Trade, Shift-Share, Export Performance. 


\section{COMPÉTITIVITÉ DES EXPORTATIONS MONDIALES: UNE ANALYSE À PARTS DE MARCHÉ CONSTANTES}

\section{RÉSUMÉ}

La période 1995-2002 est marquée par un léger ralentissement de la progression des échanges mondiaux en dollars : en volume, le commerce mondial a progressé de 5.4\% sur les années 19952002 par rapport à 6,2\% sur les dix années précédentes. Dans ces conditions, le dynamisme des exportations du "Sud" est remarquable (9,4\% de progression moyenne annuelle) et fait augmenter de 5,5 points leur part du marché mondial.

Au-delà de cette tendance de fond, les résultats des différents pays, au "Nord" comme au "Sud", sont contrastés. Pour les analyser, nous décomposons la croissance en volume des exportations de chaque pays en trois termes : un effet de structure géographique, un effet de structure sectoriel et un effet performance. Les pays n'ont aucune prise sur les effets de structure qui résultent de la croissance des marchés sur lesquels ils se trouvent positionnés du fait de leur spécialisation initiale. En revanche, le dernier effet indique la façon dont la performance propre de l'exportateur sur la période lui fait gagner (ou perdre) des parts de marché. Cette performance tient pour une part que l'on peut isoler, aux qualités d'adaptation des spécialisations sectorielle et géographique ; pour le reste, elle résulte des autres formes de la compétitivité (prix, qualité, etc.). Pour simplifier, on appellera "compétitivité" cette composante résiduelle de la performance.

Partant du commerce bilatéral de plus de 200 pays dans plus de 5000 produits entre 1995 et 2002, nous sélectionnons 88 pays et agrégeons les produits pour parvenir à 65 secteurs qui sont des combinaisons d'industries et de stades de production. Cette sélection des flux commerciaux comprend le commerce entre les Etats membre de l'Union européenne. La méthode utilisée s'apparente à une analyse à parts de marché constantes mais présente l'avantage d'une indépendance de la décomposition structurelle par rapport à l'ordre de prise en compte des dimensions géographique et sectorielle. Par ailleurs, elle permet une évaluation de la significativité des effets mesurés.

Un regroupement des pays en grandes zones montre que les gains de parts de marché des "pays du Sud" sont réalisés par les pays d'Europe centrale et orientale et la Turquie d'une part, par les pays émergents d'Asie de l'autre. Ces gains s'expliquent essentiellement par la compétitivité de ces pays, qui compense largement le désavantage sectoriel lié à leur spécialisation en début de période (effet de demande sectoriel). En Amérique latine, la spécialisation sectorielle constitue un handicap plus important, que l'amélioration de la compétitivité parvient juste à compenser. Quant aux pays d'Afrique et du Moyen-Orient, qui cumulent spécialisations géographiques et surtout sectorielles défavorables et mauvaise adaptation au dynamisme des marchés, ils dégagent des gains de compétitivité insuffisants pour éviter un déclin commercial prononcé.

Les effets géographiques sont généralement moins importants que les effets sectoriels. Ils résultent du fait que les échanges régionaux -qui peuvent être un vecteur essentiel du développement des échanges- et leur éventuelle intensification se situent dans un environnement plus ou moins dynamique. Ainsi, tous les pays d'Asie de l'Est et du Sud-Est, à commencer par la Chine, enregistrent un effet de demande géographique négatif du fait des conséquences régionales de la crise financière de 1997-98 et de la faiblesse chronique de la demande japonaise. La dépendance vis-à-vis des débouchés européens a, compte tenu de la faiblesse de la demande d'importation, constitué un handicap pour les exportations des pays de la région Europe- Afrique. Mais cette ori- 
entation régionale n'a pas empêché, voire a favorisé, l'insertion dans le commerce international de certains pays, particulièrement les PECO et la Turquie. Quant aux pays d'Amérique du Nord, ils bénéficient de l'intensification de leurs échanges régionaux dans le cadre de l'ALENA.

Le dynamisme sectoriel de la demande d'importation n'a été bénéfique qu'à un petit nombre de pays. Sur cette période où la croissance mondiale est tirée par l'investissement dans les technologies de l'information et de la communication et par la consommation des ménages américains, les secteurs de l'automobile, de la chimie-pharmacie, l'électronique, les matériels de télécommunication, ainsi que l'informatique et les autres équipements de transport sont ceux qui bénéficient de la demande la plus vigoureuse. En revanche, l'agriculture et l'agro-alimentaire, tout comme les industries de base (métallurgie, bois, papier, cuir, etc.), font face à une demande peu dynamique. Dans le textile et l'habillement, où les pays du Sud ont déjà acquis une part importante des marchés du Nord, c'est moins à un élargissement du marché qu'à une redistribution des parts de marché entre exportateurs que l'on assiste. Globalement, cette configuration sectorielle a bénéficié aux pays du Nord et handicapé les pays du Sud spécialisés dans les biens de consommation à faible contenu technologique. Mais au Nord comme au Sud, la correspondance tant statique que dynamique des spécialisations avec la demande internationale a été, au-delà de la compétitivité des exportateurs, une source très importante de différenciation des résultats.

La dynamique des marchés accroît l'importance d'une bonne capacité d'adaptation tout en rendant celle-ci plus difficile à maintenir dans la durée. Les changements intervenus au cours de la période 1995-2002 permettent d'illustrer ce point. En début de période, les importations du Nord (surtout américaines) sont très dynamiques. Compte tenu de leur taille, elles contribuent à $87 \%$ de la croissance des importations mondiales et "tirent" les exportations du Sud. Au cours des trois années suivantes, le ralentissement des importations du Nord n'empêche pas la dynamique des exportations du Sud de se renforcer. Mais le plus remarquable sur cette période est le fait que le Sud n'apparaît plus seulement comme un fournisseur du Nord (on parle "d'atelier du monde" à propos de la Chine) : ses importations progressent très fortement (de $+3,4 \%$ à $+9,3 \%$ en moyenne annuelle), leur contribution à la croissance du commerce mondial est pratiquement multipliée par quatre. Ce basculement dans la localisation des marchés porteurs est en partie conjoncturel. Mais il est symptomatique des changements qui pourraient affecter l'environnement international à moyen terme : correction des déséquilibres macroéconomiques américains, renouvellement des produits et des technologies, tensions sur les prix des biens primaires du fait de la demande chinoise et de l'épuisement de certaines ressources, etc. De tels changements modifieront la composition sectorielle de la demande et affecteront les performances relatives des exportateurs.

Comparée aux Etats-Unis et au Japon, l'Union européenne réalise la meilleure performance. En partie ce résultat est du au bon positionnement des Etats membres sur le marché intra-européen. Face à l'émergence des exportateurs du Sud, la compétitivité européenne permet à l'Union de maintenir grosso modo ses parts de marché. En revanche, les pertes de compétitivité américaine et japonaise, sont sensibles et à peu près du même ordre. La forte croissance américaine n'a pas permis de compenser la perte de compétitivité-prix liée à la hausse du dollar jusqu'en 2002. A l'inverse, la faiblesse de la croissance a pu peser sur la compétitivité hors-prix du Japon, en affectant la qualité et la variété de son offre d'exportation ainsi que son dynamisme commercial. Pour les deux pays, cette moindre compétitivité est en partie compensée, pour les Etats-Unis, par leurs atouts géographiques, pour le Japon, par ses atouts sectoriels ; au total, c'est le Japon qui enregistre le recul le plus important de ses parts de marché. 


\section{RÉSUMÉ COURT}

Au cours des années 1995-2002, les gains de parts de marché réalisés par les exportateurs du Sud sont d'autant plus remarquables que la composition sectorielle de la demande d'importations leur était défavorable. Des données d'échanges détaillées par secteurs et partenaires permettent en effet de distinguer ce qui relève des performances propres aux exportateurs de ce qui résulte de leurs positions acquises sur les marchés. Sur cette période, la forte demande de produits élaborés a bénéficié aux pays développés et désavantagé la plupart des pays du Sud, notamment les moins performants d'entre eux.

L'émergence du Sud non plus seulement en tant que fournisseur du Nord mais en tant que marché en forte expansion c'est fait à travers les pays d'Europe Centrale et Occidentale et la Turquie d'un côté, et les pays asiatiques émergents d'autre côté. Ces gains sont principalement dus à la compétitivité à l'export de ces pays et qui a plus que compensé les désavantages liés à leur spécialisation sectorielle. Pour les pays d'Amérique Latine l'amélioration de la compétitivité des exportations les a aidé à surmonter l'important handicap de leur spécialisation sectorielle, toutefois sans permettre à la plupart d'entre eux de maintenir leur part de marché. Quant aux pays d'Afrique et du Moyen-Orient, ils accumulent des spécialisations sectorielles et géographiques défavorables, ainsi qu'une faible adaptation à la dynamique des marchés.

Côté Nord, l'Union européenne enregistre la meilleure performance, surtout sur le marché domestique, et parvient à maintenir sa part sur le marché mondial. Au contraire, les pertes de compétitivité et de part de marché des Etats-Unis et du Japon sont importantes et de même ordre de grandeur. Les exportateurs japonais ont souffert de l'affaiblissement général de leur base nationale, alors que le niveau élevé du dollar dans le début de la période réduisait la compétitivité des produits américains. Cependant, cet effet a été légèrement compensé par d'autres facteurs : les avantages géographiques pour les Etats-Unis, et les avantages sectoriels pour Japon.

Classification JEL : F12, F15

Mots Clefs : Commerce, Shift-Share, Performance à l'exportation. 


\title{
Trade Competitiveness: A Disaggregated VieW BY SHIFT-SHARE ANALYSIS
}

\author{
Angela CHEPTEA ${ }^{1}$ \\ Guillaume GAULIER ${ }^{2}$ \\ Soledad ZIGNAGO ${ }^{3}$
}

\section{Introduction}

Countries' export performances are usually considered as the sum of their competitive positions. The evolution of export market shares is an important element of trade competitiveness, while the latter is just a component of a nation's competitiveness defined by the European Declaration of Lisbon as the capacity to improve and raise the standard of living of its habitants by providing more and higher quality employment, and a greater social cohesion (march 2000). The gains or losses of world market shares by individual countries are often considered as an index of their trade competitiveness. However, market share growth depends also on structural factors. Due to changes in demand, a country's geographical and sectoral specialization at the beginning of the period is an important factor shaping the market share growth. Similarly, the country's ability to adapt its exports to such changes will also affect the final outcome.

The present paper studies trade competitiveness of main world countries through a shift-share analysis over the period between 1995-2002. This time period was marked by a slight slowdown in the growth of world trade. Leaving aside the overall trend, the performances of different countries from the "North" as well as from the "South" were very heterogeneous. We estimate the trade competitiveness of world countries during the 1995-2002 period and identify the factors responsible for each country's increase or drop in exports market share.

We develop a quantitative methodology that permits to break down the growth of the volume of trade of each country into three elements: a geographic structure effect, a sectoral effect and a performance effect. Furthermore, we separate the impact of a country's initial position in different markets from that of its capacity to adapt to changes on the demand side during the period. Countries have no control over structure effects which simply reflect the growth of the foreign demand (by country or product) of their initial specialization. The performance effect includes the adaptation of sectoral and geographical specializations, and a residual referred to as exports competitiveness. The latter controls for exporters' price and non price competitiveness. Differently from the traditional method employed in the literature, our procedure benefits from two major advantages. First, it yields identical results regardless the order in which trade is decomposed in geographical and sectoral factors. And secondly, by producing standard errors of each factor, it permits to evaluate their statistical significance. Thus, we are able to differentiate between com-

\footnotetext{
${ }^{1}$ TEAM - University of Paris 1 and ADIS - University of Paris XI (achepea@univ-paris1.fr).

${ }^{2}$ CEPII (gaulier@cepii.fr).

${ }^{3}$ CEPII (zignago@cepii.fr).
} 
petitiveness and structural factors, geographic and sectoral specialisation patterns, that drove the exports growth of world countries during the 1995-2002 period.

The next section gives a generalized view of the evolution of trade during a seven-years period including the late nineteen-nineties and the beginning of the twenty-first century, a period marked by a minor slowdown in the growth of world trade. Different trade dynamics of major country groups are observed. The strength of exports from the South was remarkable, leading to a rise in the share of the world market of 5.3 percentage points. Facing the emergence of Southern exporters, the North as a group encountered competitiveness and market share losses. The EU alone managed to maintain its market shares.

The third section explains the shift-share methodology used to analyse the growth of exports of the main world exporting countries. Bilateral sectoral flows are regressed on importer, exporter and sector specific dummies in order to distinguish structure and trade performance effects. A country's trade performance is further decomposed into two effects: its capacity to adapt the initial trade structure to the evolving international environment, and its competitiveness.

The following section presents the results of market share growth decomposition by country groups and geographical regions. Emerging and non emerging countries from the South have increased their market shares mainly due to the high exports performance and favourable sectoral adaptation. Developed countries except the European Union, on the contrary, have lost market shares regardless their good positioning on different markets at the beginning of the studied period. Trade dynamics by importer, and product sector, different from the observed growth rates, are also presented. Thus a country's imports growth rate is partially attributed to the trade dynamics of the products that constitute the largest part of its imports.

To measure the role played by each of the shift-share components in explaining market share growth, the relative weight of the variance of each component in the overall observed variance, together with a term collecting the covariances are computed. The competitiveness term alone verifies the tacit assumption of unitary coefficient in the conducted analysis, and explains about $87 \%$ of the exports growth rate variance. Both structural terms show less-than-unitary but statistically non significant coefficients and have a very low explanation power. Quite the opposite is obtained for adaptation effects. We use simple data analysis to group countries together into clusters, and to identify special features that coincide with different patterns of output and trade growth.

\section{A Descriptive Analysis of World Trade}

The period from 1995-2002 ${ }^{4}$ was characterised by a marked slowdown in the growth of world trade expressed in dollars: up by an annual average of $2.6 \%$, compared to $12 \%$ for the previous decade. A large part of this slowdown stems from exchange rate fluctuations of the dollar, which rose by $28 \%$ (in effective terms) over the period, compared to a $39 \%$ depreciation in the previous 10 years. Indeed, a rise of the dollar leads to a fall in the dollar value of trade carried out in other currencies (while a depreciation increases that value).

\footnotetext{
${ }^{4}$ To reduce business cycle effects, growth rates are calculated at the beginning and end of the period using a two-year average (i.e. growth for $1995=$ average of 1995-1996, for $2002=$ average of 2001-2002).
} 
The trade data employed in this paper are obtained from the BACI database. We use unit values of bilateral trade flows available in the database to express all trade flows in prices and exchange rates of 1995. A more detailed discussion of the used data is presented in the Appendix A. For each pair of countries, unit value ratios for traded 6-digit products are used to compute bilateral price indices, which in turn are used to deflate current dollar trade values. The slowdown in world trade expressed in volume terms is thus far more moderate: annual growth stood at $5.9 \%$ for $1995-2002$, compared to $6.2 \%$ for the 10 previous years. ${ }^{5}$ The strength of exports from the South is remarkable: annual average growth stood at $9.4 \%$, leading to a rise in the share of the world market of 5.3 percentage points (Table 1). In order to capture the dynamical aspect of international trade, we break down the 1995-2002 period in two sub-periods and set forth results for each of them.

Leaving aside this overall trend, the performances of different countries, from the North as well as from the South, differ. Grouping the countries into large zones shows that the increased market shares of the South have mainly come from the Central and East European Countries along with Turkey on the one hand, and the emerging Asian countries on the other hand. Table 2 gives market shares, annual growth rates of trade and contributions to the world trade growth by main regions or country groups. The North is composed by the EU, the United-States, Japan and the other industrialized countries (whose per capita GDP expressed in PPP is above the world average). The Southern countries are classified into emerging and non emerging countries. The emerging countries are those having experienced a PPP per capita GDP growth higher than the one of the North since 1980, and since 1990 in the case of East-European countries. Thus, among the 63 countries of the South that we retain, 26 are classified as emerging (See Table 12 in Appendix B).

While industrialized countries increased their exports in volume during this period with an average annual growth rate of about $4.6 \%$, Southern countries experienced a more than double growth rate. According to Table 2, the group of emerging countries, including China, accounts for $14.1 \%$ world's total exports during the 1995-2002 period and 14.4\% of worlds' demand for foreign products. Figures in Table 2 include intra-EU trade flows, which accounted for almost a quoter of global trade in 1995 and of its growth by 2002. When intra-EU trade is neglected, it becomes the second world exporter ahead of the US and the European Union (18.6\% of global market share) and the third world importer (18.7\% of global market share). Consequently, market share losses of Northern countries need to be considered with reference to the emergence of the South.

Given the outstanding commercial performances of this country and its particular place in the global economy, Chinese figures are presented separately. First among the emerging countries, China shared with the United States the role of engine of international trade. This performance was mainly due to its exports of manufactured goods towards the United States (26\% of Chinese exports are shipped to the U.S.). But from a supplier of industrialized countries, China gradually becomes a large importer, especially of Asian products (American goods represent only one tenth of Chinese imports). When the American growth is swept away in 2001, it is China that took over

\footnotetext{
${ }^{5}$ The growth in the volume of trade for 1985-1995 is calculated using figures provided by the WTO, covering manufactured goods and agricultural products: see the WTO International Trade Report 2003.
} 
Table 1: World Trade Growth in Volume 1995-2002

\begin{tabular}{|c|c|c|c|}
\hline \multicolumn{4}{|c|}{ Annual Average Growth Rate, in \% } \\
\hline Exporter & $\overline{1995 / 6-1998 / 9}$ & $1998 / 9-2001 / 2$ & $1995 / 6-2001 / 2$ \\
\hline North & 5.5 & 3.8 & 4.7 \\
\hline South & 7.9 & 10.9 & 9.4 \\
\hline World & 6.1 & 5.8 & 5.9 \\
\hline Exporter & Importer: North & Importer: South & Importer: World \\
\hline North & 4.4 & 5.4 & 4.7 \\
\hline South & 9.7 & 8.5 & 9.4 \\
\hline World & 5.8 & 6.3 & 5.9 \\
\hline \multicolumn{4}{|c|}{ Contribution to the World Trade Growth, in \% } \\
\hline & \multicolumn{3}{|c|}{$\begin{array}{l}1995 / 6-1998 / 9 \\
\end{array}$} \\
\hline Exporter & Importer: North & Importer: South & Importer: World \\
\hline North & 58.8 & 8.6 & 67.3 \\
\hline South & 27.7 & 5.0 & 32.7 \\
\hline World & 86.5 & 13.5 & 100.0 \\
\hline & \multicolumn{3}{|c|}{$1998 / 9-2001 / 2$} \\
\hline Exporter & Importer: North & Importer: South & Importer: World \\
\hline North & 26.7 & 21.3 & 47.9 \\
\hline South & 37.9 & 14.2 & 52.1 \\
\hline World & 64.6 & 35.4 & 100.0 \\
\hline \multicolumn{4}{|c|}{ Market Share in 2002 (in \%) and its variation over the period (in p.p.) } \\
\hline Exporter & Importer: North & Importer: South & Importer: World \\
\hline North & $53.7 \quad(-4.8)$ & $16.3(-0.5)$ & 70.0 \\
\hline South & $22.6 \quad(4.3)$ & $7.4 \quad(1.0)$ & $30.0 \quad(5.3)$ \\
\hline World & $76.3 \quad(-0.5)$ & $(0.5)$ & 100.0 \\
\hline
\end{tabular}

Source: The BACI database of CEPII. Computations by authors. 
World Trade Competitiveness: A Disaggregated View by Shift-Share Analysis

Table 2: World Trade Growth by Country Groups 1995-2002

\begin{tabular}{|c|c|c|c|c|c|c|c|c|}
\hline \multicolumn{9}{|c|}{ Market Share by Country Groups in 1995, (in \%) } \\
\hline \multirow[b]{2}{*}{ Exporter } & \multicolumn{7}{|c|}{$\begin{array}{ll}\text { Importer } \\
\end{array}$} & \multirow[b]{2}{*}{ Total } \\
\hline & EU & $\overline{\text { USA }}$ & Japan & $\begin{array}{l}\text { Others } \\
\text { North }\end{array}$ & China & Emerging & $\begin{array}{c}\text { Non } \\
\text { emerging }\end{array}$ & \\
\hline EU & 23.1 & 3.0 & 1.0 & 3.8 & 0.4 & 3.1 & 2.8 & 37.2 \\
\hline USA & 3.1 & . & 1.5 & 4.5 & 0.3 & 1.6 & 2.4 & 13.4 \\
\hline Japan & 1.4 & 2.6 & . & 2.2 & 0.6 & 1.9 & 0.5 & 9.2 \\
\hline Others North & 3.4 & 5.5 & 1.2 & 1.9 & 0.8 & 1.8 & 0.7 & 15.3 \\
\hline China & 0.6 & 0.9 & 0.7 & 1.3 & . & 0.4 & 0.2 & 4.1 \\
\hline Emerging & 2.6 & 1.7 & 1.3 & 1.9 & 0.4 & 1.3 & 0.9 & 10.2 \\
\hline Non emerging & 2.9 & 2.9 & 0.6 & 0.8 & 0.2 & 1.4 & 1.6 & 10.5 \\
\hline Total & 37.1 & 16.7 & 6.3 & 16.4 & 2.9 & 11.5 & 9.1 & 100.0 \\
\hline \multicolumn{9}{|c|}{ Average Annual Growth Rate of Trade by Country Group, (in \%) } \\
\hline \multirow[b]{2}{*}{ Exporter } & \multicolumn{8}{|c|}{ Importer } \\
\hline & EU & USA & Japan & $\begin{array}{l}\text { Others } \\
\text { North }\end{array}$ & China & Emerging & $\begin{array}{c}\text { Non } \\
\text { emerging }\end{array}$ & Total \\
\hline EU & 5.9 & 9.2 & 1.4 & 3.2 & 10.2 & 5.2 & 6.9 & 5.9 \\
\hline USA & 3.5 & $\cdot$ & -2.8 & 2.6 & 8.2 & -1.0 & 8.1 & 3.1 \\
\hline Japan & 3.2 & 1.6 & . & 0.7 & 8.4 & -0.1 & 5.2 & 2.1 \\
\hline Others North & 4.3 & 4.4 & 0.1 & 2.6 & 9.7 & 4.1 & 6.5 & 4.2 \\
\hline China & 16.6 & 17.0 & 11.5 & 10.2 & . & 17.7 & 20.9 & 14.2 \\
\hline Emerging & 10.1 & 8.4 & 3.3 & 5.3 & 17.6 & 7.4 & 8.3 & 8.1 \\
\hline Non emerging & 7.7 & 11.9 & 2.7 & 14.7 & 14.5 & 5.2 & 2.9 & 8.5 \\
\hline Total & 6.2 & 7.6 & 2.3 & 4.3 & 11.1 & 4.3 & 6.9 & 5.9 \\
\hline \multicolumn{9}{|c|}{ Contribution to the World Trade Growth by Country Group, (in \%) } \\
\hline \multirow[b]{2}{*}{ Exporter } & \multicolumn{8}{|c|}{ Importer } \\
\hline & EU & USA & Japan & $\begin{array}{l}\text { Others } \\
\text { North }\end{array}$ & China & Emerging & $\begin{array}{c}\text { Non } \\
\text { emerging }\end{array}$ & Total \\
\hline EU & 22.9 & 5.1 & 0.2 & 1.9 & 0.9 & 2.7 & 3.3 & 37.0 \\
\hline USA & 1.7 & . & -0.6 & 1.9 & 0.5 & -0.2 & 3.4 & 6.6 \\
\hline Japan & 0.7 & 0.6 & . & 0.2 & 0.9 & -0.0 & 0.4 & 2.9 \\
\hline Others North & 2.4 & 4.0 & 0.0 & 0.8 & 1.4 & 1.2 & 0.8 & 10.5 \\
\hline China & 2.2 & 3.3 & 1.6 & 2.5 & . & 1.6 & 0.9 & 12.2 \\
\hline Emerging & 5.0 & 2.6 & 0.7 & 1.7 & 1.7 & 1.7 & 1.4 & 14.7 \\
\hline Non emerging & 4.0 & 6.8 & 0.3 & 2.5 & 0.7 & 1.2 & 0.7 & 16.1 \\
\hline Total & 38.8 & 22.5 & 2.2 & 11.4 & 6.1 & 8.1 & 10.9 & 100.0 \\
\hline
\end{tabular}

Source: The BACI database of CEPII. Computations by authors. 
the relay of international trade. Table 2 shows indeed that, in spite of a relatively low weight at the beginning of period, China contributed largely to the world trade growth both as exporter and as importer. This is particularly noticeable in the 1999-2002 sub-period, when China registered the highest growth rate for both exports and imports: more than $17 \%$ per year (Table 10). With such a remarkable performance, it explains $16 \%$ of the growth in exports and $9 \%$ of the growth in imports (Table 11). China, the workshop of the industrialized countries, became thus a locomotive of international economy. The contribution of other countries of the South also improved at the end of the period. Around the year 2000 the South (including China) accounted for more than a half of the growth of world exports and more than a third for imports.

On the contrary, the shrinking Japanese demand for foreign goods represented by a negative growth rate of its imports in the first sub-period, and had a negative contribution to the growth of global trade (Table 11). During the second sub-period, Japan together with the United States experienced a market share loss on all industrialized countries' internal markets. Still, the United States have a large contribution to the growth of imports, explaining between a fifth and a quarter of the global growth rate.

Imports of developing countries had a significant growth during the last two decades, and are expected to expand even more in the future especially with the accelerated development of Asian and Latin American economies. This trend is reinforced by recent progress in trade liberalization: the implementation of tariff reductions negotiated at the Uruguay Round and the joining of WTO by China. The developing markets are thus becoming the markets of the future, the main source of further trade growth. The market saturation in developed countries and the important economic growth of several developing countries in recent years fed the reorientation of world trade towards the latter group.

\section{A Renewed Shift-Share Methodology Applied to Exports' Growth}

The gains or losses of world market shares by individual countries are often considered as an index of their trade competitiveness. But given changes in demand, the relative medium-term inertia of geographical and sectoral specializations partly affects such outcomes. It is therefore interesting, for a given period, to be able to distinguish the impact of a country's initial position in different markets relative to its capacity to adapt and to its competitiveness.

The traditional tool to deal with structure effects is a shift-share or constant market share analysis. The shift-share method is one of the simplest and least expensive techniques for investigating growth rates. This method was used in particular in regional studies on economic and employment growth, and has been much less applied to trade issues. Although employed originally by the regional science literature, this method can be extended to study a large number of economic issues. We apply it to asses exports growth at country level. Similar studies have been carried only at the subnational level and mainly for the North American trade. Markusen, Noponen, and Driessen (1991) use a shift-share decomposition and estimate the shares of employment growth for export and import penetration in nine U.S. regions. Hayward and Erickson (1995) have extended this model, applying it to the North American Free Trade Area. Gazel and Schwer (1998) study the growth of international exports of the U.S. states by focusing on demand conditions. The emer- 
gence of the shift-share method from regional studies can explain its scarce application to country level data (e.g. Alcantara and Blanes 2000, and Sheets and Boata 1996). The underlying feature that supports the use of this method is that exports growth rates are affected by structural effects: Countries with initial strong positions on the most dynamic markets, either geographically or by sector, benefit ceteris paribus from higher exports growth. Accordingly, "pure" performance may be distinguished from structural effects.

The most related work to our paper in the applied literature is the CEPII (1998) report on competitiveness. It covers worldwide exports and employs a traditional shift-share analysis to decompose the exports growth of a given country into a global demand effect, a sectoral composition effect, a geographical composition effect, and a competitiveness effect, captured by the residual term. In the CEPII study, the change in country $i$ 's exports from time 0 to $t$ is expressed as follows:

$$
\begin{aligned}
X_{i . .}^{t}-X_{i . .}^{0}= & r X_{i . .}^{0}+\sum_{k}\left(r_{k}-r\right) X_{i . k}^{0}+\sum_{k} \sum_{j}\left(r_{j k}-r_{k}\right) X_{i j k}^{0} \\
& +\sum_{k} \sum_{j}\left(X_{i j k}^{t}-X_{i j k}^{0}\left(1+r_{j k}\right)\right)
\end{aligned}
$$

with $j$ denoting the trading partner, $k$ the product or sector, $r$ the global trade growth rate (all countries in the sample except $i), r_{k}$ the global growth rate for product $k, r_{j k}$ the global growth rate of product $k$ and country $j$. Countries that had good market shares in products that grew the more, benefit from a favorable sectoral effect, those having good positions in the most dynamic import countries benefit from a favorable geographic effect.

One important drawback with this method is the dependence of the results on the ordering of the structure effects: Computing first geographical effects and then sectoral effects or the inverse yields different results. Jayet (1993) describes an alternative method that fixes that problem and has the additional advantage of providing standard errors for the estimates of effects. It consists in a weighted variance analysis. We adopt this latter approach and write the growth rate of sectoral bilateral exports $r_{i j k}$ as the sum of three distinct effects as follows:

$$
r_{i j k}=m+\alpha_{i}+\beta_{j}+\gamma_{k}+\varepsilon_{i j k} .
$$

$m$ is an intercept that corresponds roughly to the average growth rate of world exports, while $\alpha_{i}, \beta_{j}, \gamma_{k}$ are respectively country, partner, and sector dummies (fixed effects). Equation (2) is estimated with ordinary least squares, weighted by the initial volume of exports $X_{i j k}^{0}$.

A fixed effects estimation of $(2)$ with a constat term $(m)$ will lead to a fixed effect for each dimension to be dropped from the equation due to collinearity. Estimates obtained for the left country, partner, and sector dummies will actually represent deviations from the dropped effect, and effects for the omitted group are equal to zero. We identify two solutions for the identification problem of all parameters in (2). One can choose to drop the fixed effects corresponding to a country/partner/product of a particular interest and interpret estimated effects as deviations from results obtained for the omitted group. The latter becomes accordingly the benchmark for all trade flows in the sample. Differently, deviations from the world (sample) average can be computed by normalizing the estimated effects. We adopt this second approach and use initial trade volumes as weights to redefine the effects. Technically, the simple average of estimated effects is subtracted 
form each effect, including the omitted ones. In the rest of the paper we shall refer to $\alpha_{i}, \beta_{j}, \gamma_{k}$ as to normalized values of estimates from (2). Notice that this method generates identical results regardless of the effects omitted in the estimation procedure. This convention is made uniquely for interpretation reasons and does not alter final results in any way. Indeed, shall trade growth for a given country, partner, and group be equal to that of the average world trade, eliminating fixed effects reflecting this group from the estimated equation (2) will yield exactly the normalized effects.

Next, demand structure effects are defined using normalized fixed effects and integrated in the decomposition of trade growth. Effects are redefined and uniquely identified with:

$$
\sum_{i} \frac{X_{i . .}^{0}}{X_{i . .}^{0}} \alpha_{i}=\sum_{j} \frac{X_{. j .}^{0}}{X_{i . .}^{0}} \beta_{j}=\sum_{k} \frac{X_{. . k}^{0}}{X_{i . .}^{0}} \gamma_{k}=0 .
$$

$\sum_{j} \frac{X_{i j .}^{0}}{X_{i . .}^{0}} \hat{\beta}_{j}$ are the geographical structure or demand effects; $\sum_{k} \frac{X_{i . k}^{0}}{X_{i .}^{0}} \hat{\gamma}_{k}$ are the sectoral structure effects, and $\varepsilon_{i j k}$ is the error term. The growth rate of country $i$ exports, $r_{i}$ can then be rewritten as follows ${ }^{6}$ :

$$
r_{i}=\hat{m}+\hat{\alpha}_{i}+\sum_{j} \frac{X_{i j .}^{0}}{X_{i . .}^{0}} \hat{\beta}_{j}+\sum_{k} \frac{X_{i . k}^{0}}{X_{i . .}^{0}} \hat{\gamma}_{k}
$$

where $\hat{\alpha}_{i}$ gives an evaluation of country $i$ performance or competitiveness on foreign markets.

By construction the sector dummies contain relative price effects: differences in relative prices across product groups. Cross country price differences are dealt with via the use of trade data expressed in volume terms.

In what follows we shall focus on changes (growth) in market share rather than on exports' growth roughly. Given the previous notation, a country's exports market share growth $g_{i}$ can be expressed as follows:

$$
g_{i}=\left(1+r_{i}\right) /(1+\hat{m})-1
$$

According to equations (2) and (3), the market share growth $g_{i}$ can be decomposed into three main components:

$$
g_{i}=G E O_{i}+S E C T_{i}+P E R F O R M_{i}
$$

where

$$
G E O_{i}=\left[\sum_{j} \frac{X_{i j .}^{0}}{X_{i . .}^{0}} \hat{\beta}_{j}\right] /(\hat{m}+1)
$$

\footnotetext{
${ }^{6}$ Given a number of zero trade flows at the initial date, the export fixed effects have to be adjusted : the export growth stemming from the creation of new trade flows (not considered in the model) is attributed to the competitiveness effect.
} 


$$
S E C T_{i}=\left[\sum_{k} \frac{X_{i . k}^{0}}{X_{i . .}^{0}} \hat{\gamma}_{k}\right] /(\hat{m}+1),
$$

and

$$
\operatorname{PERFORM} M_{i}=\left(\hat{\alpha}_{i}\right) /(\hat{m}+1) .
$$

The first term corresponds to the market share growth due to the initial geographical breakdown of exports, the second to the market share growth due to the sectoral composition of exports, and the last, obtained as a residual, to the market share growth driven by the country $i$ 's export performance. This latter term at its turn can be broken down into three factors:

$$
\begin{aligned}
& A D A P T G E O_{i}=\sum_{j}\left(\frac{X_{i j}^{1}}{X_{i .}^{1}}-\frac{X_{i j .}^{0}}{X_{i .}^{0}}\right) \beta_{j} \quad \text { shows the market share growth from changes in } \\
& A D A P T S E C T_{i}=\sum_{k}\left(\frac{X_{i k}^{1}}{X_{i . .}^{1}}-\frac{X_{i . k}^{0}}{X_{i . .}^{0}}\right) \gamma_{k} \quad \text { reflects the change due to the adaptation of the } \\
& \text { sectoral breakdown of exports, and the residual } \\
& C O M P E T_{i}=\text { PERFORM }_{i}-A D A P T G E O_{i}-A D A P T S E C T_{i} \text { accounts for the com- } \\
& \text { petitiveness of country } \\
& i \text { 's exports. }
\end{aligned}
$$

Consequently, the market share growth of a given country $i$ can be written as the sum of five terms:

$$
g_{i}=G E O_{i}+S E C T_{i}+A D A P T G E O_{i}+A D A P T S E C T_{i}+C O M P E T_{i} .
$$

This final decomposition of market share growth is presented at country and group level and discussed into detail in the next section.

\section{Decomposition of Exports' Market Share Growth}

In this section we evaluate the positioning of different countries' exports between 1995 and 2002. As shown in Table 3, international trade grew during this period with an average rate of $7 \%$ per year. The best performance was recorded by developing countries, all of which increase their exports market share. With an exports growth rate below the world average, industrialized countries, on the contrary, have lost market share. Note that this outcome is found despite the fact that we consider trade between EU member countries, a region marked by a strong growth rate of imports during the period. EU losses in world market share are even more remarkable when intra-EU trade is ignored. The situation was fairly similar for imports, with two exceptions: The appreciation of the American dollar stimulated the increase of United States' consumption of goods produced abroad, while the Asian crisis has slowed down the imports of emerging countries.

We turn now to the decomposition of the market share growth according the shift-share procedure presented in section 3.. First, we estimate equation (3) and recuperate exporter, partner, and product fixed effects $\alpha_{i}, \beta_{j}$, and $\gamma_{k}$. Next, we employ this results to compute the right hand side elements of equation (6). The decomposition of exports market share growth by country is 
Table 3: Evolution of International Trade and Market Shares 1995-2002

\begin{tabular}{||l|cc|cccc||}
\hline \hline Group/country & \multicolumn{4}{|c|}{ Annual growth rate (\%) } & \multicolumn{4}{|c|}{ Market share in 2002 (\%) } \\
& Exports & Imports & Exports* & Imports* \\
\hline & 6.5 & 6.6 & 36.8 & -0.6 & 37.1 & -0.4 \\
EU & 3.3 & 8.4 & 11.0 & -2.4 & 18.5 & 1.6 \\
JSA & 2.5 & 2.7 & 7.4 & -2.1 & 5.1 & -1.3 \\
Others North & 4.9 & 4.9 & 13.9 & -1.6 & 14.9 & -1.7 \\
China & 16.4 & 13.6 & 7.0 & 2.8 & 4.2 & 1.3 \\
Emerging countries & 9.1 & 5.7 & 11.7 & 1.4 & 10.7 & -0.7 \\
Non emerging countries & 10.7 & 9.1 & 12.1 & 2.4 & 9.6 & 1.2 \\
& & & & & & \\
Total & 6.8 & 6.8 & 100 & 0 & 100 & 0 \\
\hline \hline
\end{tabular}

Note: ${ }^{*}$ Variation in market share over the period in italic.

given in Table 13 in B. Table 4 displays decomposition results for selected countries, regions and country groups.

The best performance in the North was obtained by Ireland, which increased its market share by a half. The market share evolution for other industrialized countries was very moderate, and even negative. The good positioning of these countries on most dynamic markets, at both geographic and sectoral level, at the beginning of the period was offset by the rigidity of their exports supply and the low competitiveness of their products. Meanwhile, most developing countries considerably increased their market share, greatly due to the attractive price of their exported goods. The Chinese exports performance in excess of its market share growth arises because of the negative geographic demand effect due to shrink of Japanese demand. Mexico has the most favourable geographical structure effect: A large part of its exports market share growth is attributable to the increase of its principal client, the USA. The opposite is observed for Hungary, whose important increase in market share is exclusively generated by the export competitiveness of its products and its capacity to adapt to changes in sectoral demand. Ireland benefited from the most favorable breakdown of exports by sectors, and was in the same time the champion in sectoral adaptation.

Grouping countries into large geographical zones, one can see that the increased market shares of the South have have been driven by Central and East European countries and Turkey on the one hand, and emerging Asian countries on the other hand. These gains are mainly explained by the competitiveness of these countries, which largely compensates disadvantages linked to their specialisation at the start of the period (sectoral demand effect). In Latin America, the improvement in the competitiveness just offset the major handicap of their sectoral specialisation. African and the Middle East countries accumulated both unfavourable geographic and sectoral specialisations, as well as a poor adaptation to dynamic markets. Their competitive gains have been insufficient to prevent a pronounced decline in trade.

The EU recorded the best performance in the North, compared to the United States and Japan. 
Table 4: Decomposition of exports market share growth 1995-2002 (in \%)

\begin{tabular}{|c|c|c|c|c|c|c|}
\hline & $\begin{array}{l}\text { Market } \\
\text { share } \\
\text { growth }\end{array}$ & $\begin{array}{l}\text { Geogra- } \\
\text { phic } \\
\text { demand } \\
\text { effect }\end{array}$ & $\begin{array}{l}\text { Sectoral } \\
\text { demand } \\
\text { effect }\end{array}$ & $\begin{array}{l}\text { Geogra- } \\
\text { phic } \\
\text { adap- } \\
\text { tation }\end{array}$ & $\begin{array}{l}\text { Sectoral } \\
\text { adap- } \\
\text { tation }\end{array}$ & $\begin{array}{l}\text { Competi- } \\
\text { tiveness }\end{array}$ \\
\hline \multicolumn{7}{|c|}{ Selected Countries } \\
\hline Germany & 7.8 & 2.6 & 1.6 & -1.6 & -0.2 & 5.5 \\
\hline France & -0.9 & 1.7 & 1.1 & -2.0 & 0.5 & -2.2 \\
\hline USA & -12.8 & 4.5 & 1.8 & 7.5 & 0.1 & -26.7 \\
\hline Ireland & 49.2 & 0.4 & 6.2 & -2.9 & 7.4 & 38.1 \\
\hline Hungary & 72.3 & -0.2 & -3.0 & -2.7 & 6.4 & 71.8 \\
\hline China & 59.0 & -10.9 & -6.2 & 0.1 & 1.8 & 74.2 \\
\hline Mexico & 70.8 & 5.3 & 4.5 & -2.7 & 0.5 & 63.3 \\
\hline \multicolumn{7}{|c|}{ Geographical Regions } \\
\hline Western Europe & 0.4 & 0.9 & 0.7 & -1.9 & 0.2 & 0.5 \\
\hline USA and Canada & -12.1 & 4.8 & 1.3 & 4.9 & -0.0 & -23.0 \\
\hline Asia & 2.7 & -4.2 & -0.1 & 0.2 & -0.5 & 7.3 \\
\hline Latin America & 19.1 & -0.1 & -5.0 & -0.0 & 0.3 & 23.9 \\
\hline Central and & 16.6 & 1.7 & -4.7 & -2.2 & 2.0 & 19.8 \\
\hline Eastern Europe & & & & & & \\
\hline Africa & -9.4 & -0.4 & -6.1 & -2.0 & -1.2 & 0.3 \\
\hline Rest of the World & 26.1 & -3.2 & 4.0 & -2.6 & -1.0 & 29.0 \\
\hline \multicolumn{7}{|c|}{ Country Groups } \\
\hline European Union & 1.1 & 1.1 & 0.4 & -1.8 & 0.3 & 1.1 \\
\hline USA & -12.8 & 4.5 & 1.8 & 7.5 & 0.1 & -26.7 \\
\hline Japan & -18.3 & -1.0 & 5.4 & -0.6 & -2.3 & -19.8 \\
\hline Others North & -9.1 & 0.1 & 0.2 & -0.9 & -0.5 & -8.0 \\
\hline China & 59.0 & -10.9 & -6.2 & 0.1 & 1.8 & 74.2 \\
\hline Emerging & 12.1 & -4.2 & -4.4 & 0.1 & 0.9 & 19.6 \\
\hline Non emerging & 13.5 & -0.4 & -2.2 & -1.4 & 0.1 & 17.4 \\
\hline
\end{tabular}


Facing the emergence of Southern exporters, European competitiveness permitted the Union to maintain more or less its market shares ${ }^{7}$ (see Table 4). Partially this outcome is due to the inclusion of intra-Eu trade flows in the analysis: Most EU member countries had a good positioning on the EU domestic market, market by an important growth of imports. In contrast, competitiveness losses by the US and Japan are significant and of about the same magnitude. The strong growth of the US economy was not capable of offsetting losses in price competitiveness linked to the rise of the dollar up to the year 2002. For Japan, on the other hand, weak growth may have weighed down on non-price competitiveness, affecting the quality and the variety of its export supplies, as well as its general commercial dynamism. For both countries, however, such sluggish competitiveness was compensated by other factors: the US's geographical advantages and Japan's sectoral advantages. Overall, Japan recorded the largest fall in its market share.

Within the euro area, the differences recorded by the main exporters, France and Germany, were quite limited during the period. Both countries recorded a small change in their market shares: negative for France, positive for Germany. France was relatively disadvantaged by demand effects, whereas initial geographical and sectoral specialisation favoured Germany. The latter benefited especially from strong market shares in the Central and East European countries. In contrast, France was more able than Germany to reorient its exports to dynamic sectors, such as pharmaceutical products, automobiles, other transport equipment and telecommunications. However, it is the competitiveness effect which is more clearly unfavourable for France, as of 1999. German exporters increased their export volumes by cutting prices strongly in their main export markets, whereas their French competitors increased their margins ${ }^{8}$ by passing on less of the gains accrued through the depreciation of the euro. As a result, differences in price-fixing behaviour explain the main divergences in the growth of export volumes. (In the case of the appreciation of the domestic currenty French exporters decrease their markups to a larger extent than Germans in order to keep their market shares.) In value terms, Germany and France were much closer: $-8.4 \%$ compared to $-9 \%$ respectively (with $-5.8 \%$ and $-8 \%$ in market shares). Since February 2002, the appreciation of the euro against the dollar has reversed the price-competitive conditions. When expressed in euros, exports from both countries in 2003 felled for France, and slowed down for Germany. However, their value expressed in dollars has risen at a rapid rate, clearly much above that of U.S. exports.

The evolution of market shares was more favorable for industrialized countries at the beginning of the period, when Japan was the only country of that group to shrink its exports (See Table B). In the second half of the 1995-2002 period, the entire group of countries from the North lost market share. On the contrary, developing economies reinforced their positions during the last part of the period. This achievement was due to the increased competitiveness of Chinese products,

\footnotetext{
${ }^{7}$ While the rise of the dollar during the period reduced the volume market share of the United States, it also tended to raise the market share expressed in dollars relative to other zones, especially the European Union, which mainly trades outside the dollar zone. Thus, at current prices and exchange rates, even though EU competitiveness is greater than that of the US, the latter recorded a smaller fall in its market share (-5.2\%) compared to the EU (-10\%).

${ }^{8}$ The margins of French exporters also benefited from the fall in unit production costs, so that French cost competitiveness improved by about $30 \%$ during the period, as opposed to $10 \%$ for Germany (see DREE, Dossiers, Le commerce de la France en 2002, www.dree.org/economie).
} 
the improved geographic structure of emerging countries' supply, and the more dynamic global demand for products exported by non emerging countries.

The geographic effects are generally less influential than the sectoral effects. The geographical structural effect reflects the original exports orientation toward the most dynamic markets of the period. For instance, countries having large market shares in the NAFTA or China have benefited from a positive geographical effect. This is the case of North and Central America countries at the beginning of the period, and of Asian countries afterwards. In other words, geographical effects result from the fact that regional trade flows - which may be a crucial vector to trade development and their intensification are situated in an environment that is more or less dynamic. As a result, all countries in East and South-East Asia, starting with China, experienced a negative geographical demand effect due to the regional consequences of the 1997-98 financial crisis and the chronic weakness of Japanese demand. Similarly, given the weakness of import demand, the dependency with respect to European outlets is a major handicap for countries in the Europe-Africa region. Still, this regional orientation has not prevented, but rather favoured the integration of Turkey and certain Central and East European countries into the international trade. As for countries in North America, the intensification of regional trade within the NAFTA facilitated the provision of the demanding American market.

Table 15 displays the decomposition of the market share growth when intra-EU trade is ignored. Results for other countries of the sample remain almost unchanged. Significant difference in results are observed only for a number of European countries. A higher market share growth compared to the case when intra-EU trade flows are considered (Table 13) reflects a better positioning on trade with non members, while a lower market share growth shows that the country benefits from a better positioning on intra-EU trade. Accordingly, the reinforced growth rates for Germany, Ireland and Greece show that these countries's exports outside the Union grew more rapidly than their exports to other EU members. In particular, German exports represent a large share of Central and East European countries' markets. Lower market share growth for France, Belgium, Spain, and Portugal reveals the high dependency of these countries' exports on the internal EU market.

Note that by construction, trade dynamics by exporter, importer, or product (sector) in the decomposition of exports growth given by equation (3) are independent from each other, and therefore different from the observed growth rates. The growth rate of a country's exports, as computed and displayed in official statistical records, ignores structural changes of trade. Therefore, it reflects not only the growth of exports arising from the expansion of country's supply capacity, but also the growth acquired via changes in the geographical and sectoral composition of its exports. Thus, the increase of the share of products with the highest growth rate throughout the period in country's total exports will enhance the exports growth rate. Likewise, shipping more to countries that registered the largest increase in their imports will cause a similar change in the growth rate of country's exports. However, none of the last two effects can be attributed to the country' own exports dynamics. The very rationale of the decomposition of growth rates given by (3) is to unravel these kind of effects, by providing true exporter, importer and sectoral dynamics. Hence, the difference between exports growth rate $r_{i}$ and exporter's dynamics $\alpha_{i}$ is due to changes in the sectoral and geographical breakdown of exports registered during the period.

Similarly, the growth rate of a country's imports is partially attributed to the trade dynamics of 
the products that constitute the largest part of its demand, and of export markets that account for the biggest share of its foreign supply. Table 5 shows the growth rate $r_{j}$ of imports, and importerspecific trade dynamics $\beta_{j}$ for different countries and groups of countries. Corresponding results for all countries in the panel are shown in Table 16 of the Appendix B. It is straightforward that a high growth rate of imports only rarely testify of a similar pure importer's dynamics. According to these findings, the most dynamic importing markets are the United States, China, Mexico, and Central and East European countries. On the contrary, Japan, others North countries, Asian and Latin American countries are characterized by the most declining demand for foreign products. The growth of European Union's demand for goods produced abroad is situated around the world's average rate. Among the EU, Spain and Ireland were the most dynamic importers with $30 \%$ and respectively $40 \%$ of growth in 1995-2002. On the other edge, Germany and Sweden shrank the volume of their imports by almost a tenth.

Table 5: Importing markets' dynamics 1995-2002, (\%)

\begin{tabular}{||l|rr||}
\hline \hline Country/group & Imports Growth Rate $r_{j}$ & \multicolumn{2}{|c|}{$\begin{array}{l}\text { Importer-specific } \\
\text { Trade Dynamics } \beta_{j}\end{array}$} \\
\hline European Union & 43.1 & 3.0 \\
Germany & 31.5 & -9.4 \\
United Kingdom & 43.2 & 2.9 \\
France & 40.4 & 0.8 \\
United States of America & 55.5 & 10.6 \\
Japan & 14.5 & -30.6 \\
Others North & 28.7 & -15.5 \\
China & 88.3 & 60.1 \\
Emerging countries & 29.1 & -7.4 \\
Non emerging countries & 49.6 & 8.1 \\
\hline \hline
\end{tabular}

The sectoral pattern of growth in imports demand has favored only a small number of countries. The global trade growth was driven by investment in information and communication technologies and by household consumption in the United States. Overall sectoral trends have been benefical to countries from the North and have handicapped Southern countries specialized in low technology consumer goods. Annual growth rates $r_{k}$ and sectoral dynamics $\gamma_{k}$ for different groups of products are displayed in Table 6. Results of a more detailed disaggregation are presented in the Appendix B (Table 17).

During the 1995-2002 period, the automobiles, chemicals and pharmaceuticals, electronics, telecommunications equipment, computers and transport equipment benefited from the strongest demand. Food and agriculture, together with other basic industries (metals, wood, paper, leather etc.) have experienced weak demand. The textile and clothing sectors, where the South has already acquired a major share of Northern markets, are less marked by an expansion of markets and more by a redistribution of market shares among exporters.

In the North Singapore, Ireland and Japan have profited the most from their favorable sec- 
Table 6: Sectoral Dynamics of Trade

\begin{tabular}{|c|c|c|c|c|c|c|}
\hline Product group & \multicolumn{3}{|c|}{$\begin{array}{l}\text { Annual Growth Rate } \\
\text { of World Exports (\%) }\end{array}$} & \multicolumn{3}{|c|}{$\begin{array}{l}\text { Sectoral Dynamic } \\
\text { (\% per year) }\end{array}$} \\
\hline Food and live animals & 2.4 & 1.9 & 2.9 & -5.6 & -5.1 & -3.8 \\
\hline Beverages and tobacco & 3.8 & 4.2 & 3.4 & -1.8 & -1.4 & -1.9 \\
\hline Crude materials, inedible & 1.0 & -1.0 & 3.2 & -7.4 & -8.2 & -3.9 \\
\hline Mineral fuels; lubricants & 8.4 & 2.2 & 15.0 & 2.6 & -5.8 & 11.6 \\
\hline Animal and vegetable oils, fats & 0.5 & 3.5 & -2.4 & -10.9 & -5.4 & -9.8 \\
\hline Chemicals and related products & 7.4 & 6.6 & 8.3 & 2.4 & 0.7 & 3.1 \\
\hline Manufactured goods & 3.8 & 3.6 & 4.0 & -3.5 & -2.7 & -2.9 \\
\hline Machinery and transp. equip. & 7.0 & 8.7 & 5.2 & 2.1 & 3.5 & 0.1 \\
\hline Misc. manufactured articles & 6.4 & 7.1 & 5.7 & -1.0 & 0.3 & -2.0 \\
\hline Other commodities & 0.3 & 7.4 & -6.4 & -8.3 & -3.9 & -13.4 \\
\hline
\end{tabular}

toral trade specializations (a 9\%, 10\% and respectively $6 \%$ rise in market shares). New Zealand, Australia, and Greece, largely specialized in food and agriculture recorded negative sectoral effects (a -13\%, -14\%, and $-13 \%$ loss of market share, respectively). The best performance in terms of adapting to changes in sectoral demand was shown by Portugal $(+2.8 \%)$, followed by Ireland $(+2.1 \%)$, and Belgium $(+2.0 \%)$.

In the South, the sectoral effect was positive in only for oil producing countries, characterized by a positive dynamic of the demand for lubricants and transport equipment, and the withdrawal from heavy industries and textiles, Mexico $(+4.5 \%)$, that reinforced its initial specialization in automobiles and in the IT sector, and withdrew from heavy industries and agriculture, Malaysia $(+4 \%)$, Philippines $(+1.2 \%)$, that benefited from a good placing in the IT sector, and Slovenia $(+1.1 \%)$. The latter four also experienced positive sectoral adaptation. South-East Asian countries, including China, and most transition countries, including Russia, encountered relatively small negative sectoral effects, which they overcame through a proper adaptation to the global demand. The dynamic behaviour of markets increases the importance of the successful capacity to adapt, though making the latter difficult to maintain over time. With two exceptions, transition countries also were quite successful in adapting the sectoral structure of their exports. Their strong competitiveness gains and adaptation to demand were largely enough to outweigh their initial disadvantage.

Other countries, generally situated in a worse position in the specter of sectoral structure in 1995, were unable to reorient their exports towards the most dynamic sectors. This is the case of countries specialized in textiles and clothing (Bangladesh, Egypt, Pakistan, Sri Lanka, and Tunisia), and Sub-Saharan African countries that export mainly simple manufactured and agricultural products and whose demand and prices have been falling. 


\section{Beyond Trade Performance: Explaining the Results}

\subsection{A look at the data by clustering}

Using simple data analysis, countries are grouped together into clusters. It is then possible to point out special features that coincide with different patterns of output and trade growth. We use cluster and factor analysis on a database that includes our decomposition of export growth: sectoral and geographical specialization, sectoral and geographical adaptation (of specialization) and trade competitiveness, real GDP growth, and real (effective) exchange rate growth. Figure 1 offers a graphical representation of the obtained clusters.

Most dynamic countries, both in term of trade and output, are grouped together. Countries in this cluster (labelled “+” in Figure 1) include China, Vietnam, Mexico, Ireland, and a number of Central and East European countries (Croatia, Czech Republic, Hungary, Lithuania, and Poland) and also share good sectoral adaptation. Their currencies, initially low, have often appreciated in parallel with their GDP, suggesting a Balassa-Samuelson effect.

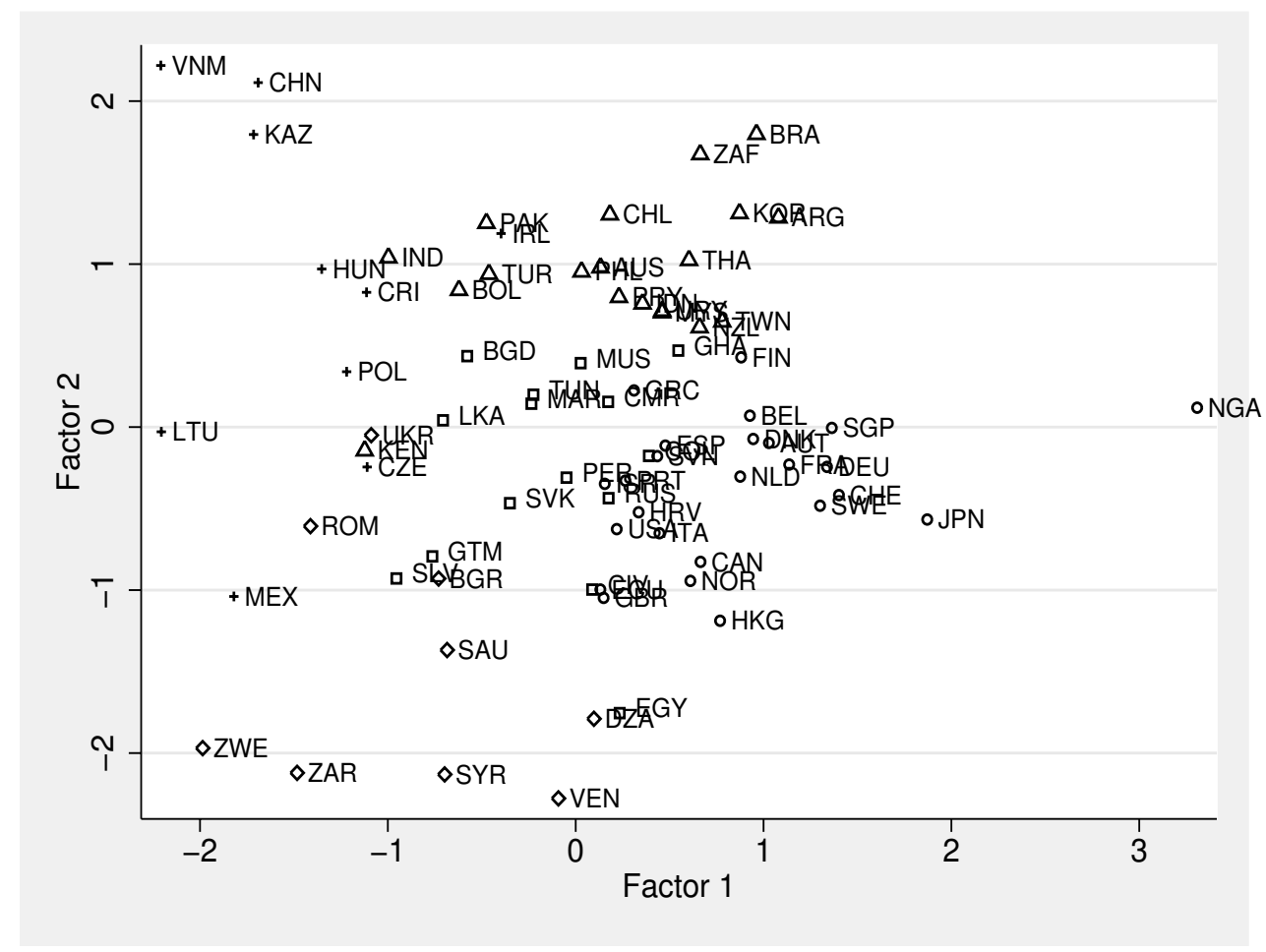

Figure 1: Clustering 
Next in order of exports performance comes a group formed of South American countries, Australia, New-Zealand, South Africa, and some Asian countries (India, Pakistan, Korea, Philippines, Taiwan, Thailand), labelled " $\triangle$ " in Figure 1. They faced highly unfavorable sectoral and especially geographical specialization, due to the weakening of European and Japanese demand, which they could not overcome even through an appropriate re-orientation of export flows. The latter is less true for Asian countries, which while hurt by the drop in the Japanese demand, and the 1997 crisis, increased their exports to China. Countries from this group were also marked by high real exchange rates.

A third group of widely geographically spread countries comprises exporters with a good initial geographic structure. This cluster is labelled " $\square$ " in Figure 1 and includes Peru, Guatemala, Bangladesh, Sri Lanka, Tunisia, Egypt, Cameroun, Morocco, Slovenia, Slovakia, and Russia. Despite the generally unfavourable sectoral breakdown of their exports, and poor adaptation to changing patterns of world demand, both in terms of trading partners and exported products, some of these countries succeeded in increasing their market share due to the competitiveness of their products. Others from the same group were less successful and registered small market share losses.

The next group includes a number of East European and oil-exporting countries (labelled " $\diamond$ " in Figure 1). It assembles countries which suffered from an adverse initial geographical structure of exports, as well as a poor sectoral adaptation of exports structure. Exports of these countries suffered from a poor geographical adaptation to the international demand. Moreover, all this countries had a lower than world average real GDP growth.

Most industrialized countries including the European Union, Japan, Canada, and the United States, form the last cluster (labelled "O" in Figure 1), quite heterogeneous in terms of exports' growth and performance. The members of this group share both low export and growth record, and all of them lost market share during the considered period. Regardless the generally favourable geographical and sectoral breakdown of exports, most of these countries had a poor adaptation to changing patterns of world demand both in terms of trading partners and exported products.

\subsection{Explaining Export Performance}

Exporters and importers tend to engage in long-run trade relationships, finding that shifting business between countries is costly. Therefore both domestic (supply variables) and foreign factors (demand variables) should affect a country's export performance.

After having discussed the magnitude of the demand, adaptation and competitiveness factors and their impact on the market share of distinct countries and country groups, we would like to infer to which extent each of them explains market share evolutions in average, i.e. for the entire sample of countries. The simplest way to picture this is to look at correlation coefficients between the market share growth and each of its components, according to the decomposition given by equation 6. Table 7 shows the correlation coefficients between the different components of the market share growth decomposition. It is straightforward that adaptation, both sectoral and geographical, and competitiveness factors explain the bulk of variations in market share. Meanwhile, except for competitiveness and geographical adaptation, correlation coefficients between the five components are fairly low, in line with our assumption of independent effects.

The displacement in the location of dynamic markets is partly linked to the business cycle. 
Table 7: Correlation matrix

\begin{tabular}{l|rrrrrr}
\hline & $g_{i}$ & $G E O_{i}$ & $S E C T_{i}$ & $\begin{array}{c}A D A P T \\
G E O_{i}\end{array}$ & $\begin{array}{c}A D A P T \\
S^{S E C T_{i}}\end{array}$ & $\begin{array}{c}C O M- \\
P E T_{i}\end{array}$ \\
\hline$g_{i}$ & 1.00 & & & & & \\
$G E O_{i}$ & 0.06 & 1.00 & & & & \\
SECT $_{i}$ & 0.02 & 0.22 & 1.00 & & & \\
ADAPTGEO $_{i}$ & 0.26 & -0.26 & -0.24 & 1.00 & & \\
ADAPTSECT $_{i}$ & 0.70 & 0.01 & -0.21 & 0.48 & 1.00 & \\
COMPET $_{i}$ & 0.95 & -0.09 & -0.23 & 0.64 & 0.22 & 1.00 \\
\hline
\end{tabular}

But it is also symptomatic of changes which could affect the international environment in the medium term: the correction of US macroeconomic imbalances, the renewal of products and technologies, pressures on primary products prices due to the Chinese demand and the exhaustion of certain resources, etc. Such changes will modify the sectoral composition of demand and will affect the relative performance of exporting countries.

A different way of measuring the role played by each of the shift-share components in explaining market share growth over the 1995-2002 period for the 88 countries in the sample is to compute the relative weight of the variance of each component in the overall observed variance, together with a term collecting the covariances.

Since an exporter's market share growth can be decomposed into the sum of three factors (section 3.), it is easy to obtain

$$
\begin{aligned}
& \operatorname{var}\left(g_{i}\right)=\operatorname{var}\left(G E O_{i}\right)+\operatorname{var}\left(S E C T_{i}\right)+\operatorname{var}\left(A D A P T G E O_{i}\right) \\
& +\operatorname{var}\left(A D A P T S E C T_{i}\right)+\operatorname{var}\left(C O M P E T_{i}\right) \\
& +2\left[\operatorname{cov}\left(G E O_{i}, S E C T_{i}\right)+\operatorname{cov}\left(G E O_{i}, A D A P T G E O_{i}\right)\right. \\
& +\operatorname{cov}\left(G E O_{i}, A D A P T S E C T_{i}\right)+\operatorname{cov}\left(G E O_{i}, C_{C M P E T_{i}}\right) \\
& +\operatorname{cov}\left(S E C T_{i}, A D A P T G E O_{i}\right)+\operatorname{cov}\left(S E C T_{i}, A D A P T S E C T_{i}\right) \\
& +\operatorname{cov}\left(S E C T_{i}, C O M P E T_{i}\right)+\operatorname{cov}\left(A D A P T G E O_{i}, A D A P T S E C T_{i}\right) \\
& \left.+\operatorname{cov}\left(A D A P T G E O_{i}, C O M P E T_{i}\right)+\operatorname{cov}\left(A D A P T S E C T_{i}, C O M P E T_{i}\right)\right] .
\end{aligned}
$$

As shown in table 8 , market share variance is explained in a proportion of $87 \%$ by the variance of the exports' competitiveness. The other four factors amount jointly to less than $10 \%$ of the market share variance. 
Table 8: Share in total variance by components

\begin{tabular}{||l|r||}
\hline \hline Component & Share in total variance \\
\hline $\operatorname{var}\left(G E O_{i}\right) / \operatorname{var}\left(g_{i}\right)$ & 0.0133 \\
$\operatorname{var}\left(S E C T_{i}\right) / \operatorname{var}\left(g_{i}\right)$ & 0.0612 \\
$\operatorname{var}\left(A D A P T G E O_{i}\right) / \operatorname{var}\left(g_{i}\right)$ & 0.0090 \\
$\operatorname{var}\left(A D A P T S E C T_{i}\right) / \operatorname{var}\left(g_{i}\right)$ & 0.0105 \\
$\operatorname{var}\left(C O M P E T_{i}\right) / \operatorname{var}\left(g_{i}\right)$ & 0.8738 \\
$2 \sum\left(\operatorname{cov} / \operatorname{var}\left(g_{i}\right)\right)$ & 0.0323 \\
\hline Total & 1.0000 \\
\hline \hline
\end{tabular}

In order to have a sharper appreciation of the role played by each component, we also test whether market share growth can be explained by a model including a single component of the shift-share decomposition presented in section 3.. More precisely, we estimate the following five equations and report results table 9 .

$$
\begin{aligned}
& g_{i}=a_{1}+b_{1} \cdot G E O_{i}+\varepsilon_{1} \\
& g_{i}=a_{2}+b_{2} \cdot S E C T_{i}+\varepsilon_{2} \\
& g_{i}=a_{3}+b_{3} \cdot A D A P T G E O_{i}+\varepsilon_{3} \\
& g_{i}=a_{4}+b_{4} \cdot A D A P T S E C T_{i}+\varepsilon_{4} \\
& g_{i}=a_{5}+b_{5} \cdot C O M P E T_{i}+\varepsilon_{5}
\end{aligned}
$$

Table 9: Parameter estimates of the variance decomposition

\begin{tabular}{||lccccc||}
\hline \hline & $\hat{a}$ & Std.Err. & $\hat{b}$ & Std.Err. & $R^{2}$ \\
\hline Model $G E O_{i}$ & 4.65 & $(4.84)$ & 0.52 & $(0.93)$ & 0.0036 \\
Model $S E C T_{i}$ & 4.66 & $(6.10)$ & 0.07 & $(0.44)$ & 0.0003 \\
Model $A D A P T G E O_{i}$ & 7.16 & $(4.74)$ & 2.75 & $(1.10)$ & 0.0681 \\
Model $A D A P T S E C T_{i}$ & 0.14 & $(3.41)$ & 6.84 & $(0.75)$ & 0.4896 \\
Model $C O M P E T_{i}$ & -10.79 & $(1.49)$ & 1.02 & $(0.03)$ & 0.9119 \\
\hline \hline
\end{tabular}

The competitiveness term alone verifies the tacit assumption of unitary coefficient in the conducted analysis, and explains about $91 \%$ of the exports growth rate variance. Both structural terms show less-than-unitary but statistically non significant coefficients and have a very low explanation power. Quite the opposite is obtained for sectoral and geographic adaptation effects. Alone they explain $49 \%$ and respectively $7 \%$ of the exports growth rate.

The various effects we have distinguished statistically, however, are not independent. A good geographical and sectoral specialisation - whose direct impact on market share gains was identified - may have a negative, indirect impact on performance: by insuring "automatic" gains in market share, it may limit incentives to improve competitiveness. We regress the export growth against 
its various components resulting from the shift-share analysis, leaving aside competitiveness. The analysis conducted up to now involves imposing a unitary coefficient on each of the structural and adaptation effects. These constraints are rejected: the impact of sectoral demand is found to have a coefficient close to unity for Southern countries, but it is not statistically different from 0 for the North. The sectoral adaptation effect is significantly greater than 1 (about 4 for the South, and 3 for the North). The geographic demand and adaptation effects are negative though not significant. The results are then checked to see whether they are qualitatively unchanged if the observations are weighted by initial export levels or if per capita GDP growth and the real effective exchange rate are incorporated into the regression analysis, as these two variables may explain gains in competitiveness. We conclude that indirect effects of a good geographical specialisation (or adaptation) are negative while a good initial sectoral specialisation may have an impact on competitiveness (in the case of Southern countries) which is at best neutral. In contrast, there is a positive link between the adaptation of sectoral specialisation and competitiveness: The capacity to "seek out" growth in dynamic market segments and the capacity for increasing market share in all export markets move together.

\section{Conclusion}

The prominent feature of world imports in the two past decades was the emergence of new actors. Successful developing countries progressively reoriented their trade flows toward the emerging market. While retaining strong and growing positions in industrialised markets (the basis for their export-led development), they gain market share in the worldwide market. The gains or losses of world market shares by individual countries are often considered as an index of their trade competitiveness. However, market share growth depends also on structural factors. Due to changes in demand, a country's geographical and sectoral specialization at the beginning of the period is an important factor shaping the market share growth. Similarly, the country's ability to adapt its exports to such changes will also affect the final outcome.

The present paper analyses trade competitiveness of a large sample of countries, accounting for more than $80 \%$ of global trade, from 1995 to 2002 . This time period was marked by a slight slowdown in the growth of world trade. The performances of different countries from the "North" as well as from the "South" were very heterogeneous. We estimate the trade competitiveness of each country in the sample and identify the factors responsible for the observed increase or fall in its exports market share.

We develop and apply an improved shift-share methodology that permits to break down the growth of the volume of trade into a geographic structure effect, a sectoral effect and a performance effect. The latter includes the country's adaptation of sectoral and geographical specializations to international trade patterns, and a residual referred to as exports competitiveness. Thus, we are able to separate the impact of a country's initial position in different markets from that of its capacity to adapt to changes in demand occurred during the period. The left competitiveness effect controls for both price and non price competitiveness of exported products. Differently from the traditional shift-share method employed in the literature, our technique benefits from two important advantages. The size of effects does not depend on the order in which trade is decomposed in geographical and sectoral factors. Our procedure also permits to recuperate standard errors for 
each factor and, therefore, to assess the statistical significance of results.

Different trade dynamics of major country groups are observed. The remarkable growth of exports from the South led to a rise in their share of the world market of 5.3 percentage points. Emerging and non emerging countries from the South have increased their market shares mainly due to the high exports performance and favourable sectoral adaptation. Facing the emergence of Southern exporters, the group of industrialized countries encountered competitiveness and market share losses. Among them, the EU alone managed to maintain its market shares. Other developed countries have lost market shares regardless their good positioning on different markets at the beginning of the studied period. We also use simple data analysis to group countries together into clusters, and to identify special features that coincide with different patterns of output and trade growth.

We measure the role played by each of the shift-share components in explaining market share growth, by the relative weight of the variance of each component in the overall observed variance. The competitiveness term alone verifies the tacit assumption of unitary coefficient in the conducted analysis, and explains about $87 \%$ of the exports growth rate variance. Geographic and sector structural terms display less-than-unitary but statistically non significant coefficients and have a very low explanation power, while the opposite is obtained for adaptation effects. 


\section{References}

- Alcantara Escolano V. and J. Blanes Cristóbal (2000), Efectos explicativos de las exportaciones de le UE a los paises de Europa Central y Oriental: Metodologia y primeros resultados, Informacion Comercial Espanola Revista de Economia no. 786 pp. 183-190

- Baier S.L. and H. J. Bergstrand (2001), The growth of world trade: tariffs, transport costs, and income similarity, Journal of International Economics, vol. 53, pp. 1-27

- Baldwin R.E. (2003), Openness and growth: What's the empirical relationship?, NBER Working Paper No. 9578

- CEPII (1998), Compétitivité des Nations, Economica, Paris.

- Cheptea A., G. Gaulier and S.Zignago (2004), Marché mondial : positions acquises et performances, La lettre du CEPII, No. 231

- Edwards S. (1993), Openness, trade liberalization, and growth in developing countries, Journal of Economic Literature, Vol. 31, pp. 1358-1393

- Esteban J. (2000), Regional convergence in Europe and industry mix: a shift-share analysis, Regional Science and Urban Economics, vol. 30, pp. 353-364

- Gazel R. and R.K. Schwer (1998), Growth of international exports among the states: Can a modified shift-share analysis explain it?, International Regional Science Review, Vol. 21(2), pp. 185-204

- Hayward D. and R.A. Erickson (1995), The North American trade of U.S. states: A comparative analysis of industrial shipments, 1983-91, International Regional Science Review, Vol. 18(1), pp.1-31

- Jayet H. (1993), Analyse spatiale quantitative : une introduction, Economica, Paris

- Markusen A.R., H. Noponen, and K. Driessen (1991), International trade, productivity, and U.S. regional job growth: A shift-share interpretation, International Regional Science Review, vol. 14(1), pp. 15-39

- Redding S. and A. Venables (2003), Geography and export performance: external market access and internal supply capacity, CEPR Working Paper No. 3807

- Sheets N. and S. Boata (1996), Eastern European export performance during transition, International Finance Discussion Papers No. 562, Board of Governors of the Federal Reserve System

- Worz J. (2003), Skill intensity in foreign trade and economic growth, WIIW Working Paper No. 25

- WTO International Trade Report 2003

http://www.wto.org/english/news_e/pres03_e/pr348_e.htm. 


\section{A Trade data}

The bilateral trade data are taken from the CEPII's BACI database which provides harmonised trade data for more than 200 countries and 5000 products, between 1995 and 2002. BACI is based on COMTRADE UN trade data. Original procedures have been developed to harmonise data: the evaluation of the quality of country declarations to average mirror flows, the evaluation of CIF rates to reconcile import and export declarations, the conversion in tonnes of other units of quantities exchanged. A detailed description of this database is available at http://www. cepii.fr/anglaisgraph/research/mbdci/baci .htm.

For this paper, we aggregate BACI data on the SITC Rev. 3 2-digit classification and select 88 countries. An underlying feature of this work is the use of volume trade data. Indeed, BACI permits the calculation of bilateral unit values indices. The deflatation of trade values provides trade data in volume. This approach permits us to evaluate true exports performance, dropping out the part due to price fluctuations, and to obtain more reliable results. We are thus able to reflect the true impact of exchange rate appreciation/ depreciation and other elements generating changes in price levels on a country's exports capacity.

\section{B Detailed Results}

Table 10: Average Annual Growth Rate of Trade by Country Group

\begin{tabular}{|c|c|c|c|c|c|c|c|c|}
\hline \multirow[b]{2}{*}{ Exporter } & \multicolumn{8}{|c|}{ 1995-1998, (in \%) } \\
\hline & EU & USA & Japan & Oth.North & China & Emerg. & Non emerg. & Total \\
\hline EU & 7.5 & 11.6 & -1.6 & 3.4 & 4.8 & 4.1 & 5.6 & 6.7 \\
\hline USA & 8.5 & . & -1.8 & 5.5 & 4.7 & -3.2 & 11.8 & 5.6 \\
\hline Japan & 10.7 & 4.3 & . & 2.6 & 4.0 & -7.8 & 6.1 & 2.8 \\
\hline Others North & 6.5 & 5.9 & -2.7 & 2.1 & 3.6 & 0.2 & -0.5 & 3.9 \\
\hline China & 16.2 & 17.4 & 5.8 & 7.0 & . & 8.3 & 15.6 & 11.1 \\
\hline Emerging & 11.7 & 10.0 & 0.5 & 7.3 & 13.5 & 5.4 & 5.0 & 7.9 \\
\hline Non emerg. & 6.5 & 10.9 & -2.2 & 14.0 & 1.7 & 3.7 & 0.5 & 6.5 \\
\hline Total & 8.0 & 8.7 & -0.6 & 5.0 & 5.5 & 1.0 & 6.2 & 6.1 \\
\hline \multirow[b]{2}{*}{ Exporter } & \multicolumn{8}{|c|}{ 1999-2002, (in \%) } \\
\hline & EU & USA & Japan & Oth.North & China & Emerg. & Non emerg. & Total \\
\hline EU & 4.3 & 6.9 & 4.4 & 3.1 & 15.8 & 6.4 & 8.2 & 5.1 \\
\hline USA & -1.4 & · & -3.7 & -0.1 & 12.0 & 1.3 & 4.5 & 0.7 \\
\hline Japan & -3.8 & -1.0 & . & -1.1 & 13.0 & 8.2 & 4.3 & 1.4 \\
\hline Others North & 2.1 & 3.0 & 3.0 & 3.1 & 16.1 & 8.3 & 14.0 & 4.6 \\
\hline China & 17.1 & 16.5 & 17.5 & 13.4 & . & 27.9 & 26.4 & 17.5 \\
\hline Emerging & 8.6 & 6.8 & 6.3 & 3.4 & 21.9 & 9.4 & 11.7 & 8.2 \\
\hline Non emerg. & 8.9 & 13.0 & 7.7 & 15.4 & 28.9 & 6.8 & 5.2 & 10.5 \\
\hline Total & 4.4 & 6.6 & 5.2 & 3.6 & 17.1 & 7.8 & 7.7 & 5.8 \\
\hline
\end{tabular}

Source: The BACI database of CEPII. Computations by authors. 
Table 11: Contribution to the World Trade Growth by Country Group

\begin{tabular}{||l|ccccccc|c||}
\hline \hline \multirow{2}{*}{ Exporter } & \multicolumn{7}{|c||}{ 1995-1998, Importer } \\
\cline { 2 - 9 } & EU & USA & Japan & Oth.North & China & Emerg. & Non emerg. & Total \\
\hline EU & 28.6 & 6.1 & -0.2 & 2.0 & 0.3 & 2.1 & 2.5 & 41.4 \\
USA & 4.4 &. & -0.4 & 4.0 & 0.2 & -0.8 & 4.8 & 12.3 \\
Japan & 2.5 & 1.8 &. & 0.9 & 0.4 & -2.1 & 0.5 & 4.0 \\
Others North & 3.7 & 5.3 & -0.5 & 0.6 & 0.5 & 0.0 & -0.1 & 9.6 \\
China & 1.7 & 2.8 & 0.7 & 1.5 &. & 0.5 & 0.5 & 7.8 \\
Emerging & 5.3 & 3.0 & 0.1 & 2.3 & 1.0 & 1.1 & 0.8 & 13.5 \\
Non emerg. & 3.1 & 5.4 & -0.2 & 2.0 & 0.1 & 0.8 & 0.1 & 11.3 \\
\hline Total & 49.4 & 24.3 & -0.5 & 13.3 & 2.6 & 1.8 & 9.2 & 100.0 \\
\hline \hline & & & 7 & $1999-2002$, Importer & & \\
Exporter & EU & USA & Japan & Oth.North & China & Emerg. & Non emerg. & Total \\
\hline EU & 17.8 & 4.3 & 0.6 & 1.8 & 1.3 & 3.3 & 4.0 & 33.1 \\
USA & -0.7 &. & -0.7 & -0.1 & 0.7 & 0.3 & 2.1 & 1.6 \\
Japan & -0.9 & -0.4 &. & -0.3 & 1.4 & 1.8 & 0.4 & 1.9 \\
Others North & 1.2 & 2.8 & 0.5 & 0.9 & 2.3 & 2.2 & 1.5 & 11.3 \\
China & 2.6 & 3.8 & 2.5 & 3.4 &. & 2.5 & 1.3 & 16.0 \\
Emerging & 4.7 & 2.3 & 1.2 & 1.1 & 2.4 & 2.1 & 1.9 & 15.8 \\
Non emerg. & 4.7 & 8.0 & 0.7 & 2.9 & 1.2 & 1.6 & 1.3 & 20.3 \\
\hline Total & 29.3 & 20.8 & 4.7 & 9.8 & 9.3 & 13.7 & 12.4 & 100.0 \\
\hline \hline
\end{tabular}

Source: The BACI database of CEPII. Computations by authors.

Table 12: Exporting and Importing Countries

\begin{tabular}{||l|ccc||}
\hline \hline Country & $\begin{array}{c}\text { Market share growth } \\
1995-2002(\%)\end{array}$ & $\begin{array}{c}\text { Market share in } \\
2002(\%)\end{array}$ & $\begin{array}{c}\text { Change in market share } \\
1995-2002(\mathrm{p} . \mathrm{p} .)\end{array}$ \\
\hline European Union & -1.63 & 36.83 & -0.61 \\
Germany & 5.72 & 9.48 & 0.51 \\
France & -5.56 & 4.85 & -0.29 \\
United Kingdom & -15.61 & 4.31 & -0.80 \\
Italy & -12.28 & 3.89 & -0.54 \\
Netherlands & -7.08 & 3.08 & -0.23 \\
Belgium & 3.41 & 3.05 & 0.10 \\
Spain & 16.01 & 2.01 & 0.28 \\
Ireland & 50.42 & 1.53 & 0.51 \\
Sweden & -12.07 & 1.34 & -0.18 \\
Austria & 13.48 & 1.12 & 0.13 \\
Denmark & -2.56 & 0.84 & -0.02 \\
Finland & -1.99 & 0.75 & -0.02 \\
Portugal & -3.16 & 0.45 & -0.01 \\
Greece & -23.32 & 0.16 & -0.05 \\
& & & \\
USA & -18.01 & 11.02 & -2.42 \\
Japan & -21.75 & 7.43 & -2.07 \\
\hline
\end{tabular}


World Trade Competitiveness: A Disaggregated View by Shift-Share Analysis

Table 12: Exporting and Importing Countries (continued)

\begin{tabular}{||l|ccc||}
\hline \hline Country & Market share growth & Market share in & Change in market share \\
& 2002 $(\%)$ & $1995-2002(\mathrm{p} . \mathrm{p})$. \\
\hline Others North & -10.21 & 13.85 & -1.57 \\
Canada & -15.17 & 4.14 & -0.74 \\
Singapore & -8.30 & 1.99 & -0.18 \\
Switzerland & -10.77 & 1.51 & -0.18 \\
Australia & -2.17 & 1.05 & -0.02 \\
Norway & -9.79 & 1.02 & -0.11 \\
Hong Kong & -25.01 & 0.82 & -0.27 \\
New Zealand & -15.94 & 0.23 & -0.04 \\
Israel & 14.15 & 0.51 & 0.06 \\
Taiwan & -3.16 & 2.58 & -0.08 \\
& & & \\
China & 67.95 & 7.03 & 2.84 \\
& & & \\
Emerging & 14.04 & 11.71 & 1.44 \\
South Korea & 11.11 & 2.87 & 0.29 \\
Malaysia & 3.59 & 1.77 & 0.06 \\
Indonesia & 4.60 & 1.17 & 0.05 \\
Thailand & 4.50 & 1.16 & 0.05 \\
India & 22.91 & 0.89 & 0.17 \\
Poland & 37.06 & 0.68 & 0.18 \\
Turkey & 43.17 & 0.59 & 0.18 \\
Hungary & 84.42 & 0.55 & 0.25 \\
Chile & -1.51 & 0.33 & -0.01 \\
Slovakia & 32.57 & 0.27 & 0.07 \\
Slovenia & 2.21 & 0.17 & 0.00 \\
Egypt & -36.19 & 0.09 & -0.05 \\
Lithuania & 35.48 & 0.08 & 0.02 \\
Croatia & -23.31 & 0.07 & -0.02 \\
Tunisia & -2.02 & 0.11 & -0.00 \\
Sri Lanka & 17.81 & 0.08 & 0.01 \\
Bangladesh & 4.60 & 0.11 & -0.00 \\
Ecuador & -20.15 & 0.09 & -0.00 \\
Mauritius & -13.19 & 0.03 & 0.12 \\
Viet Nam & 86.03 & 0.27 & 0.03 \\
Sudan & 213.41 & 0.05 & 0.01 \\
Pakistan & 3.91 & 0.14 & 0.04 \\
Costa Rica & 59.51 & 0.12 & 0.01 \\
Uganda & -22.83 & 0.01 & \\
Mozambique & 182.64 & 0.01 & \\
& & & \\
Non emerging & 24.47 & 12.12 & \\
\hline
\end{tabular}


Table 12: Exporting and Importing Countries (continued)

\begin{tabular}{|c|c|c|c|}
\hline Country & $\begin{array}{l}\text { Market share growth } \\
1995-2002(\%)\end{array}$ & $\begin{array}{l}\text { Market share in } \\
2002(\%)\end{array}$ & $\begin{array}{l}\text { Change in market share } \\
1995-2002 \text { (p.p.) }\end{array}$ \\
\hline Mexico & 81.11 & 2.83 & 1.27 \\
\hline Russia & 27.06 & 1.66 & 0.35 \\
\hline Saudi Arabia & 23.91 & 1.43 & 0.28 \\
\hline Brazil & 1.80 & 1.07 & 0.02 \\
\hline Philippines & 44.23 & 0.73 & 0.22 \\
\hline Czech Republic & 42.10 & 0.66 & 0.20 \\
\hline South Africa & 8.79 & 0.62 & 0.05 \\
\hline Argentina & -7.45 & 0.48 & -0.04 \\
\hline Ukraine & 106.36 & 0.25 & 0.13 \\
\hline Romania & 30.06 & 0.24 & 0.05 \\
\hline Bulgaria & 4.64 & 0.08 & 0.00 \\
\hline Zimbabwe & -13.43 & 0.04 & -0.01 \\
\hline Colombia & -17.93 & 0.22 & -0.05 \\
\hline Morocco & 6.98 & 0.14 & 0.01 \\
\hline Peru & 13.51 & 0.13 & 0.02 \\
\hline Nigeria & -15.95 & 0.24 & -0.05 \\
\hline Côte d'Ivoire & -38.68 & 0.05 & -0.03 \\
\hline Cameroon & -29.59 & 0.03 & -0.01 \\
\hline Kenya & -14.94 & 0.03 & -0.00 \\
\hline Venezuela & -15.93 & 0.40 & -0.08 \\
\hline Uruguay & -33.96 & 0.04 & -0.02 \\
\hline Senegal & 30.87 & 0.01 & 0.00 \\
\hline Syria & 30.01 & 0.10 & 0.02 \\
\hline Guatemala & -1.94 & 0.06 & -0.00 \\
\hline Ghana & -26.61 & 0.02 & -0.01 \\
\hline Tanzania & -13.37 & 0.01 & -0.00 \\
\hline Algeria & -11.06 & 0.27 & -0.03 \\
\hline Bolivia & 1.16 & 0.03 & 0.00 \\
\hline Paraguay & -15.35 & 0.02 & -0.00 \\
\hline Madagascar & -7.60 & 0.01 & -0.00 \\
\hline El Salvador & 25.24 & 0.04 & 0.01 \\
\hline Zambia & -31.70 & 0.02 & -0.01 \\
\hline Ethiopia & -31.34 & 0.01 & -0.00 \\
\hline Kazakhstan & 354.76 & 0.13 & 0.10 \\
\hline Mali & -58.47 & 0.00 & -0.00 \\
\hline Zaire & -16.28 & 0.02 & -0.00 \\
\hline Burkina Faso & -66.08 & 0.00 & -0.00 \\
\hline Total & & 100 & 0.00 \\
\hline
\end{tabular}

Source: The BACI database of CEPII. Computations by authors. Differences market share growth rates with respect to Tables 13 and 4 are due to the exclusion of outlier points in computations of results displayed in the latter two. 
World Trade Competitiveness: A Disaggregated View by Shift-Share Analysis

Table 13: Decomposition of Exports Market Share Growth 1995-2002

\begin{tabular}{|c|c|c|c|c|c|c|}
\hline Country & $\begin{array}{l}\text { Market } \\
\text { share } \\
\text { growth }\end{array}$ & $\begin{array}{l}\text { Geogra- } \\
\text { phic } \\
\text { demand } \\
\text { effect }\end{array}$ & $\begin{array}{l}\text { Sectoral } \\
\text { demand } \\
\text { effect }\end{array}$ & $\begin{array}{l}\text { Geogra- } \\
\text { phic } \\
\text { adap- } \\
\text { tation }\end{array}$ & $\begin{array}{l}\text { Sectoral } \\
\text { adap- } \\
\text { tation }\end{array}$ & $\begin{array}{l}\text { Competi- } \\
\text { tiveness }\end{array}$ \\
\hline European Union & 1.05 & $\begin{array}{c}1.05 \\
(0.02)\end{array}$ & $\begin{array}{c}0.42 \\
(0.05)\end{array}$ & -1.84 & 0.28 & $\begin{array}{c}1.13 \\
(0.05)\end{array}$ \\
\hline Germany & 7.78 & $\begin{array}{c}2.56 \\
(0.02)\end{array}$ & $\begin{array}{c}1.57 \\
(0.05)\end{array}$ & -1.61 & -0.22 & $\begin{array}{c}5.48 \\
(0.05)\end{array}$ \\
\hline United Kingdom & -11.73 & $\begin{array}{c}1.08 \\
(0.02)\end{array}$ & $\begin{array}{c}4.09 \\
(0.05)\end{array}$ & -1.31 & 0.99 & $\begin{array}{c}-16.58 \\
(0.05)\end{array}$ \\
\hline France & -0.91 & $\begin{array}{c}1.71 \\
(0.03)\end{array}$ & $\begin{array}{c}1.12 \\
(0.05)\end{array}$ & -2.04 & 0.55 & $\begin{array}{l}-2.24 \\
(0.05)\end{array}$ \\
\hline Italy & -9.01 & $\begin{array}{c}0.21 \\
(0.02)\end{array}$ & $\begin{array}{l}-3.27 \\
(0.05)\end{array}$ & -1.12 & -0.71 & $\begin{array}{l}-4.11 \\
(0.05)\end{array}$ \\
\hline Netherlands & -3.92 & $\begin{array}{c}0.64 \\
(0.02)\end{array}$ & $\begin{array}{l}-1.36 \\
(0.05)\end{array}$ & -2.66 & -0.00 & $\begin{array}{l}-0.54 \\
(0.05)\end{array}$ \\
\hline Belgium & 6.96 & $\begin{array}{l}-0.35 \\
(0.02)\end{array}$ & $\begin{array}{l}-1.87 \\
(0.05)\end{array}$ & -2.41 & 0.64 & $\begin{array}{l}10.95 \\
(0.05)\end{array}$ \\
\hline Spain & 15.09 & $\begin{array}{c}0.47 \\
(0.02)\end{array}$ & $\begin{array}{l}-0.84 \\
(0.05)\end{array}$ & -1.17 & -1.07 & $\begin{array}{l}17.70 \\
(0.05)\end{array}$ \\
\hline Sweden & -9.63 & $\begin{array}{l}-0.15 \\
(0.02)\end{array}$ & $\begin{array}{c}2.89 \\
(0.05)\end{array}$ & -2.58 & -1.25 & $\begin{array}{l}-8.54 \\
(0.05)\end{array}$ \\
\hline Ireland & 49.21 & $\begin{array}{c}0.42 \\
(0.02)\end{array}$ & $\begin{array}{c}6.17 \\
(0.05)\end{array}$ & -2.91 & 7.44 & $\begin{array}{l}38.08 \\
(0.06)\end{array}$ \\
\hline Austria & 12.16 & $\begin{array}{c}1.04 \\
(0.02)\end{array}$ & $\begin{array}{l}-1.38 \\
(0.05)\end{array}$ & -2.49 & -0.66 & $\begin{array}{l}15.65 \\
(0.06)\end{array}$ \\
\hline Denmark & -2.67 & $\begin{array}{l}-1.85 \\
(0.02)\end{array}$ & $\begin{array}{l}-0.91 \\
(0.05)\end{array}$ & -2.91 & 1.14 & $\begin{array}{c}1.86 \\
(0.06)\end{array}$ \\
\hline Finland & -0.09 & $\begin{array}{l}-1.76 \\
(0.02)\end{array}$ & $\begin{array}{l}-2.78 \\
(0.05)\end{array}$ & -1.66 & 1.42 & $\begin{array}{c}4.70 \\
(0.06)\end{array}$ \\
\hline Portugal & -2.55 & $\begin{array}{c}2.56 \\
(0.02)\end{array}$ & $\begin{array}{l}-6.23 \\
(0.05)\end{array}$ & -1.83 & 0.26 & $\begin{array}{c}2.70 \\
(0.06)\end{array}$ \\
\hline Greece & -21.56 & $\begin{array}{c}0.17 \\
(0.03)\end{array}$ & $\begin{array}{l}-13.65 \\
(0.05)\end{array}$ & -1.91 & 2.55 & $\begin{array}{l}-8.72 \\
(0.07)\end{array}$ \\
\hline$U S A$ & -12.83 & $\begin{array}{c}4.45 \\
(0.02)\end{array}$ & $\begin{array}{c}1.85 \\
(0.05)\end{array}$ & 7.50 & 0.06 & $\begin{array}{l}-26.70 \\
(0.05)\end{array}$ \\
\hline Japan & -18.34 & $\begin{array}{l}-1.01 \\
(0.02)\end{array}$ & $\begin{array}{c}5.40 \\
(0.05)\end{array}$ & -0.57 & -2.34 & $\begin{array}{l}-19.81 \\
(0.05)\end{array}$ \\
\hline Others North & -9.09 & $\begin{array}{c}0.14 \\
(0.02)\end{array}$ & $\begin{array}{c}0.24 \\
(0.05)\end{array}$ & -0.93 & -0.52 & $\begin{array}{l}-8.02 \\
(0.05)\end{array}$ \\
\hline Canada & -10.01 & $\begin{array}{c}5.63 \\
(0.01)\end{array}$ & $\begin{array}{l}-0.41 \\
(0.05)\end{array}$ & -2.43 & -0.29 & $\begin{array}{l}-12.50 \\
(0.05)\end{array}$ \\
\hline
\end{tabular}


Table 13: Decomposition of Exports Market Share Growth 1995-2002 (continued)

\begin{tabular}{|c|c|c|c|c|c|c|}
\hline Country & $\begin{array}{l}\text { Market } \\
\text { share } \\
\text { growth }\end{array}$ & $\begin{array}{l}\text { Geogra- } \\
\text { phic } \\
\text { demand } \\
\text { effect }\end{array}$ & $\begin{array}{l}\text { Sectoral } \\
\text { demand } \\
\text { effect }\end{array}$ & $\begin{array}{l}\text { Geogra- } \\
\text { phic } \\
\text { adap- } \\
\text { tation }\end{array}$ & $\begin{array}{l}\text { Sectoral } \\
\text { adap- } \\
\text { tation }\end{array}$ & $\begin{array}{l}\text { Competi- } \\
\text { tiveness }\end{array}$ \\
\hline Taiwan & -6.44 & $\begin{array}{l}-1.45 \\
(0.02)\end{array}$ & $\begin{array}{l}-0.14 \\
(0.05)\end{array}$ & 4.24 & 0.71 & $\begin{array}{l}-9.80 \\
(0.05)\end{array}$ \\
\hline Singapore & -10.29 & $\begin{array}{l}-5.86 \\
(0.02)\end{array}$ & $\begin{array}{c}8.54 \\
(0.05)\end{array}$ & -1.59 & -2.53 & $\begin{array}{l}-8.85 \\
(0.05)\end{array}$ \\
\hline Switzerland & -7.08 & $\begin{array}{l}-1.74 \\
(0.02)\end{array}$ & $\begin{array}{c}3.30 \\
(0.05)\end{array}$ & -2.04 & -0.91 & $\begin{array}{l}-5.68 \\
(0.05)\end{array}$ \\
\hline Norway & -10.58 & $\begin{array}{l}-0.17 \\
(0.02)\end{array}$ & $\begin{array}{c}4.72 \\
(0.05)\end{array}$ & -2.84 & -0.05 & $\begin{array}{l}-12.24 \\
(0.06)\end{array}$ \\
\hline Australia & -4.99 & $\begin{array}{l}-8.63 \\
(0.02)\end{array}$ & $\begin{array}{c}-13.92 \\
(0.06)\end{array}$ & -1.55 & 0.88 & $\begin{array}{l}18.23 \\
(0.06)\end{array}$ \\
\hline Hong Kong & -22.46 & $\begin{array}{c}5.30 \\
(0.02)\end{array}$ & $\begin{array}{l}-3.37 \\
(0.05)\end{array}$ & -1.61 & -2.10 & $\begin{array}{l}-20.69 \\
(0.06)\end{array}$ \\
\hline Israel & 11.07 & $\begin{array}{c}0.07 \\
(0.02)\end{array}$ & $\begin{array}{l}-0.56 \\
(0.05)\end{array}$ & -1.24 & 0.39 & $\begin{array}{l}12.41 \\
(0.06)\end{array}$ \\
\hline New Zealand & -14.63 & $\begin{array}{l}-5.28 \\
(0.02)\end{array}$ & $\begin{array}{c}-14.18 \\
(0.06)\end{array}$ & -0.16 & -1.35 & $\begin{array}{c}6.35 \\
(0.07)\end{array}$ \\
\hline China & 59.01 & $\begin{array}{l}-10.90 \\
(0.02)\end{array}$ & $\begin{array}{l}-6.18 \\
(0.05)\end{array}$ & 0.05 & 1.82 & $\begin{array}{l}74.22 \\
(0.05)\end{array}$ \\
\hline Emerging & 12.11 & $\begin{array}{l}-4.17 \\
(0.02)\end{array}$ & $\begin{array}{l}-4.42 \\
(0.05)\end{array}$ & 0.13 & 0.94 & $\begin{array}{l}19.62 \\
(0.06)\end{array}$ \\
\hline South Korea & 8.64 & $\begin{array}{l}-3.15 \\
(0.02)\end{array}$ & $\begin{array}{l}-0.59 \\
(0.05)\end{array}$ & 2.72 & 1.82 & $\begin{array}{c}7.85 \\
(0.05)\end{array}$ \\
\hline Malaysia & 3.48 & $\begin{array}{l}-8.14 \\
(0.02)\end{array}$ & $\begin{array}{c}3.92 \\
(0.05)\end{array}$ & -0.01 & -0.02 & $\begin{array}{c}7.72 \\
(0.05)\end{array}$ \\
\hline Indonesia & 3.14 & $\begin{array}{l}-7.71 \\
(0.02)\end{array}$ & $\begin{array}{l}-5.84 \\
(0.05)\end{array}$ & -1.64 & -0.45 & $\begin{array}{l}18.79 \\
(0.06)\end{array}$ \\
\hline Thailand & 11.37 & $\begin{array}{l}-6.39 \\
(0.02)\end{array}$ & $\begin{array}{l}-4.10 \\
(0.05)\end{array}$ & 0.01 & 0.86 & $\begin{array}{l}21.00 \\
(0.06)\end{array}$ \\
\hline India & 13.37 & $\begin{array}{l}-4.75 \\
(0.03)\end{array}$ & $\begin{array}{l}-11.95 \\
(0.05)\end{array}$ & -0.20 & 0.36 & $\begin{array}{l}29.91 \\
(0.06)\end{array}$ \\
\hline Poland & 33.79 & $\begin{array}{l}-1.72 \\
(0.02)\end{array}$ & $\begin{array}{l}-6.66 \\
(0.05)\end{array}$ & -1.45 & 3.22 & $\begin{array}{l}40.40 \\
(0.06)\end{array}$ \\
\hline Turkey & 36.69 & $\begin{array}{l}-1.28 \\
(0.03)\end{array}$ & $\begin{array}{l}-13.90 \\
(0.05)\end{array}$ & -1.32 & 1.85 & $\begin{array}{l}51.34 \\
(0.06)\end{array}$ \\
\hline Chile & -3.16 & $\begin{array}{l}-5.24 \\
(0.03)\end{array}$ & $\begin{array}{l}-14.69 \\
(0.06)\end{array}$ & 6.06 & -1.48 & $\begin{array}{l}12.19 \\
(0.06)\end{array}$ \\
\hline
\end{tabular}


World Trade Competitiveness: A Disaggregated View by Shift-Share Analysis

Table 13: Decomposition of Exports Market Share Growth 1995-2002 (continued)

\begin{tabular}{|c|c|c|c|c|c|c|}
\hline Country & $\begin{array}{l}\text { Market } \\
\text { share } \\
\text { growth }\end{array}$ & $\begin{array}{l}\text { Geogra- } \\
\text { phic } \\
\text { demand } \\
\text { effect }\end{array}$ & $\begin{array}{l}\text { Sectoral } \\
\text { demand } \\
\text { effect }\end{array}$ & $\begin{array}{l}\text { Geogra- } \\
\text { phic } \\
\text { adap- } \\
\text { tation }\end{array}$ & $\begin{array}{l}\text { Sectoral } \\
\text { adap- } \\
\text { tation }\end{array}$ & $\begin{array}{l}\text { Competi- } \\
\text { tiveness }\end{array}$ \\
\hline Hungary & 72.30 & $\begin{array}{c}-0.21 \\
(0.02)\end{array}$ & $\begin{array}{l}-3.00 \\
(0.05)\end{array}$ & -2.68 & 6.36 & $\begin{array}{l}71.82 \\
(0.07)\end{array}$ \\
\hline Slovakia & 28.74 & $\begin{array}{c}8.96 \\
(0.03)\end{array}$ & $\begin{array}{l}-6.10 \\
(0.05)\end{array}$ & -6.84 & 2.56 & $\begin{array}{l}30.16 \\
(0.07)\end{array}$ \\
\hline Slovenia & 4.68 & $\begin{array}{c}1.09 \\
(0.03)\end{array}$ & $\begin{array}{c}0.40 \\
(0.05)\end{array}$ & -3.01 & 0.34 & $\begin{array}{c}5.87 \\
(0.08)\end{array}$ \\
\hline Viet Nam & 79.53 & $\begin{array}{l}-9.15 \\
(0.02)\end{array}$ & $\begin{array}{l}-12.98 \\
(0.05)\end{array}$ & 2.11 & 0.93 & $\begin{array}{l}98.62 \\
(0.08)\end{array}$ \\
\hline Egypt & -36.91 & $\begin{array}{c}2.44 \\
(0.03)\end{array}$ & $\begin{array}{l}-1.93 \\
(0.05)\end{array}$ & -2.74 & -8.17 & $\begin{array}{l}-26.51 \\
(0.08)\end{array}$ \\
\hline Pakistan & 5.29 & $\begin{array}{l}-3.34 \\
(0.02)\end{array}$ & $\begin{array}{l}-21.88 \\
(0.05)\end{array}$ & 1.95 & -0.64 & $\begin{array}{l}29.19 \\
(0.08)\end{array}$ \\
\hline Ecuador & -21.91 & $\begin{array}{c}1.31 \\
(0.02)\end{array}$ & $\begin{array}{l}-7.80 \\
(0.05)\end{array}$ & -5.56 & -0.19 & $\begin{array}{l}-9.67 \\
(0.08)\end{array}$ \\
\hline Tunisia & 5.12 & $\begin{array}{c}2.54 \\
(0.02)\end{array}$ & $\begin{array}{c}-13.48 \\
(0.05)\end{array}$ & -3.82 & -0.38 & $\begin{array}{l}20.26 \\
(0.08)\end{array}$ \\
\hline Bangladesh & 11.12 & $\begin{array}{c}1.56 \\
(0.02)\end{array}$ & $\begin{array}{c}-18.84 \\
(0.05)\end{array}$ & -3.01 & -2.24 & $\begin{array}{l}33.64 \\
(0.09)\end{array}$ \\
\hline Croatia & -18.86 & $\begin{array}{c}2.44 \\
(0.03)\end{array}$ & $\begin{array}{l}-4.69 \\
(0.05)\end{array}$ & -3.81 & 1.44 & $\begin{array}{c}-14.24 \\
(0.09)\end{array}$ \\
\hline Costa Rica & 20.91 & $\begin{array}{c}6.67 \\
(0.02)\end{array}$ & $\begin{array}{l}-15.60 \\
(0.05)\end{array}$ & -0.91 & 10.33 & $\begin{array}{l}20.42 \\
(0.09)\end{array}$ \\
\hline Sri Lanka & 11.45 & $\begin{array}{c}1.46 \\
(0.02)\end{array}$ & $\begin{array}{l}-16.93 \\
(0.05)\end{array}$ & -3.26 & -2.14 & $\begin{array}{l}32.32 \\
(0.10)\end{array}$ \\
\hline Lithuania & 16.81 & $\begin{array}{l}-3.85 \\
(0.03)\end{array}$ & $\begin{array}{l}-10.61 \\
(0.05)\end{array}$ & -1.00 & 3.41 & $\begin{array}{l}28.85 \\
(0.10)\end{array}$ \\
\hline Mauritius & -12.24 & $\begin{array}{c}1.47 \\
(0.04)\end{array}$ & $\begin{array}{l}-20.19 \\
(0.06)\end{array}$ & -4.12 & -0.91 & $\begin{array}{l}11.51 \\
(0.13)\end{array}$ \\
\hline Uganda & -42.67 & $\begin{array}{c}0.70 \\
(0.05)\end{array}$ & $\begin{array}{l}-29.32 \\
(0.06)\end{array}$ & -9.15 & 1.96 & $\begin{array}{l}-6.85 \\
(0.20)\end{array}$ \\
\hline Sudan & 281.66 & $\begin{array}{l}-0.53 \\
(0.02)\end{array}$ & $\begin{array}{c}-29.32 \\
(0.06)\end{array}$ & 20.89 & 33.45 & $\begin{array}{c}257.17 \\
(0.21)\end{array}$ \\
\hline Mozambique & 175.69 & $\begin{array}{c}0.28 \\
(0.04)\end{array}$ & $\begin{array}{l}-20.70 \\
(0.06)\end{array}$ & -6.02 & 4.86 & $\begin{array}{l}197.27 \\
(0.35)\end{array}$ \\
\hline Non emerging & 13.50 & $\begin{array}{c}-0.43 \\
(0.03)\end{array}$ & $\begin{array}{l}-2.20 \\
(0.05)\end{array}$ & -1.37 & 0.08 & $\begin{array}{l}17.41 \\
(0.07)\end{array}$ \\
\hline
\end{tabular}


Table 13: Decomposition of Exports Market Share Growth 1995-2002 (continued)

\begin{tabular}{|c|c|c|c|c|c|c|}
\hline Country & $\begin{array}{l}\text { Market } \\
\text { share } \\
\text { growth }\end{array}$ & $\begin{array}{l}\text { Geogra- } \\
\text { phic } \\
\text { demand } \\
\text { effect }\end{array}$ & $\begin{array}{l}\text { Sectoral } \\
\text { demand } \\
\text { effect }\end{array}$ & $\begin{array}{l}\text { Geogra- } \\
\text { phic } \\
\text { adap- } \\
\text { tation }\end{array}$ & $\begin{array}{l}\text { Sectoral } \\
\text { adap- } \\
\text { tation }\end{array}$ & $\begin{array}{l}\text { Competi- } \\
\text { tiveness }\end{array}$ \\
\hline Russia & 0.89 & $\begin{array}{c}4.05 \\
(0.03)\end{array}$ & $\begin{array}{l}-1.40 \\
(0.05)\end{array}$ & -2.37 & 1.01 & $\begin{array}{l}-0.40 \\
(0.05)\end{array}$ \\
\hline Mexico & 70.84 & $\begin{array}{c}5.25 \\
(0.01)\end{array}$ & $\begin{array}{c}4.53 \\
(0.05)\end{array}$ & -2.75 & 0.52 & $\begin{array}{l}63.29 \\
(0.05)\end{array}$ \\
\hline Saudi Arabia & 28.32 & $\begin{array}{l}-5.53 \\
(0.02)\end{array}$ & $\begin{array}{l}11.99 \\
(0.05)\end{array}$ & -3.40 & -2.40 & $\begin{array}{l}27.66 \\
(0.06)\end{array}$ \\
\hline Brazil & -2.44 & $\begin{array}{l}-6.12 \\
(0.03)\end{array}$ & $\begin{array}{l}-13.12 \\
(0.06)\end{array}$ & 3.79 & 1.41 & $\begin{array}{l}11.60 \\
(0.06)\end{array}$ \\
\hline Philippines & 13.54 & $\begin{array}{l}-5.69 \\
(0.01)\end{array}$ & $\begin{array}{c}1.14 \\
(0.05)\end{array}$ & -0.32 & 1.72 & $\begin{array}{l}16.70 \\
(0.06)\end{array}$ \\
\hline South Africa & 1.32 & $\begin{array}{l}-6.64 \\
(0.05)\end{array}$ & $\begin{array}{r}-13.72 \\
(0.05)\end{array}$ & 0.55 & 0.43 & $\begin{array}{l}20.70 \\
(0.06)\end{array}$ \\
\hline Argentina & -11.01 & $\begin{array}{l}-8.61 \\
(0.03)\end{array}$ & $\begin{array}{l}-11.83 \\
(0.06)\end{array}$ & 0.77 & 0.37 & $\begin{array}{c}8.30 \\
(0.06)\end{array}$ \\
\hline Venezuela & -17.98 & $\begin{array}{c}3.46 \\
(0.02)\end{array}$ & $\begin{array}{c}7.48 \\
(0.05)\end{array}$ & -0.49 & -2.64 & $\begin{array}{l}-25.79 \\
(0.06)\end{array}$ \\
\hline Czech Republic & 35.72 & $\begin{array}{c}1.31 \\
(0.03)\end{array}$ & $\begin{array}{l}-5.42 \\
(0.05)\end{array}$ & -3.64 & 3.78 & $\begin{array}{l}39.69 \\
(0.06)\end{array}$ \\
\hline Nigeria & -12.49 & $\begin{array}{c}3.90 \\
(0.03)\end{array}$ & $\begin{array}{l}10.79 \\
(0.05)\end{array}$ & -5.56 & -1.51 & $\begin{array}{l}-20.11 \\
(0.07)\end{array}$ \\
\hline Algeria & -10.71 & $\begin{array}{c}3.71 \\
(0.02)\end{array}$ & $\begin{array}{l}15.21 \\
(0.05)\end{array}$ & -2.11 & -2.38 & $\begin{array}{l}-25.14 \\
(0.07)\end{array}$ \\
\hline Colombia & -16.07 & $\begin{array}{c}3.78 \\
(0.03)\end{array}$ & $\begin{array}{l}-9.97 \\
(0.05)\end{array}$ & -0.54 & 1.34 & $\begin{array}{l}-10.68 \\
(0.07)\end{array}$ \\
\hline Ukraine & 1.91 & $\begin{array}{l}-3.91 \\
(0.03)\end{array}$ & $\begin{array}{l}-15.38 \\
(0.05)\end{array}$ & 1.40 & -1.13 & $\begin{array}{l}20.93 \\
(0.07)\end{array}$ \\
\hline Romania & 25.61 & $\begin{array}{c}0.85 \\
(0.03)\end{array}$ & $\begin{array}{l}-11.59 \\
(0.05)\end{array}$ & -1.21 & -0.08 & $\begin{array}{l}37.64 \\
(0.07)\end{array}$ \\
\hline Morocco & 1.03 & $\begin{array}{c}3.39 \\
(0.03)\end{array}$ & $\begin{array}{c}-16.35 \\
(0.06)\end{array}$ & -3.53 & 0.32 & $\begin{array}{l}17.20 \\
(0.08)\end{array}$ \\
\hline Peru & 11.94 & $\begin{array}{c}2.73 \\
(0.03)\end{array}$ & $\begin{array}{r}-16.25 \\
(0.06)\end{array}$ & -2.96 & -3.75 & $\begin{array}{l}32.16 \\
(0.08)\end{array}$ \\
\hline Bulgaria & -11.89 & $\begin{array}{c}0.19 \\
(0.03)\end{array}$ & $\begin{array}{l}-11.13 \\
(0.05)\end{array}$ & -0.52 & -2.13 & $\begin{array}{c}1.69 \\
(0.09)\end{array}$ \\
\hline Kazakhstan & 14.20 & $\begin{array}{l}-7.91 \\
(0.02)\end{array}$ & $\begin{array}{l}-13.65 \\
(0.05)\end{array}$ & 4.52 & 7.12 & $\begin{array}{l}24.11 \\
(0.09)\end{array}$ \\
\hline Côte d'Ivoire & -34.75 & $\begin{array}{c}1.80 \\
(0.06)\end{array}$ & $\begin{array}{l}-22.52 \\
(0.06)\end{array}$ & -2.75 & -7.36 & $\begin{array}{l}-3.93 \\
(0.10)\end{array}$ \\
\hline
\end{tabular}


World Trade Competitiveness: A Disaggregated View by Shift-Share Analysis

Table 13: Decomposition of Exports Market Share Growth 1995-2002 (continued)

\begin{tabular}{|c|c|c|c|c|c|c|}
\hline Country & $\begin{array}{l}\text { Market } \\
\text { share } \\
\text { growth }\end{array}$ & $\begin{array}{l}\text { Geogra- } \\
\text { phic } \\
\text { demand } \\
\text { effect }\end{array}$ & $\begin{array}{l}\text { Sectoral } \\
\text { demand } \\
\text { effect }\end{array}$ & $\begin{array}{l}\text { Geogra- } \\
\text { phic } \\
\text { adap- } \\
\text { tation }\end{array}$ & $\begin{array}{l}\text { Sectoral } \\
\text { adap- } \\
\text { tation }\end{array}$ & $\begin{array}{l}\text { Competi- } \\
\text { tiveness }\end{array}$ \\
\hline Syria & 23.36 & $\begin{array}{c}1.82 \\
(0.02)\end{array}$ & $\begin{array}{c}4.12 \\
(0.05)\end{array}$ & -5.94 & -2.99 & $\begin{array}{l}26.35 \\
(0.09)\end{array}$ \\
\hline Guatemala & -4.55 & $\begin{array}{c}8.31 \\
(0.04)\end{array}$ & $\begin{array}{l}-19.90 \\
(0.06)\end{array}$ & -2.61 & -0.29 & $\begin{array}{c}9.95 \\
(0.10)\end{array}$ \\
\hline Uruguay & -35.37 & $\begin{array}{l}-10.67 \\
(0.03)\end{array}$ & $\begin{array}{l}-17.65 \\
(0.06)\end{array}$ & 1.20 & -0.06 & $\begin{array}{l}-8.18 \\
(0.11)\end{array}$ \\
\hline Cameroon & -26.58 & $\begin{array}{c}5.44 \\
(0.03)\end{array}$ & $\begin{array}{l}-13.68 \\
(0.06)\end{array}$ & 0.06 & 2.18 & $\begin{array}{l}-20.58 \\
(0.12)\end{array}$ \\
\hline Ghana & -54.81 & $\begin{array}{l}-0.73 \\
(0.03)\end{array}$ & $\begin{array}{l}-21.47 \\
(0.06)\end{array}$ & -1.64 & -2.24 & $\begin{array}{l}-28.72 \\
(0.13)\end{array}$ \\
\hline Zimbabwe & -25.02 & $\begin{array}{l}-3.74 \\
(0.05)\end{array}$ & $\begin{array}{l}-20.27 \\
(0.06)\end{array}$ & -4.07 & -4.01 & $\begin{array}{c}7.08 \\
(0.12)\end{array}$ \\
\hline El Salvador & 22.11 & $\begin{array}{c}9.30 \\
(0.03)\end{array}$ & $\begin{array}{l}-16.55 \\
(0.05)\end{array}$ & -2.02 & -1.88 & $\begin{array}{l}33.26 \\
(0.13)\end{array}$ \\
\hline Kenya & -22.89 & $\begin{array}{l}-4.99 \\
(0.07)\end{array}$ & $\begin{array}{l}-19.65 \\
(0.06)\end{array}$ & -5.06 & 3.04 & $\begin{array}{c}3.79 \\
(0.13)\end{array}$ \\
\hline Paraguay & -25.03 & $\begin{array}{r}-12.36 \\
(0.03)\end{array}$ & $\begin{array}{l}-23.63 \\
(0.06)\end{array}$ & -12.96 & 1.72 & $\begin{array}{l}22.22 \\
(0.14)\end{array}$ \\
\hline Zaire & -21.40 & $\begin{array}{c}3.27 \\
(0.02)\end{array}$ & $\begin{array}{l}-8.53 \\
(0.05)\end{array}$ & -1.58 & 0.30 & $\begin{array}{l}-14.85 \\
(0.15)\end{array}$ \\
\hline Bolivia & -6.88 & $\begin{array}{l}-9.08 \\
(0.03)\end{array}$ & $\begin{array}{c}-13.96 \\
(0.06)\end{array}$ & -1.39 & 2.03 & $\begin{array}{l}15.53 \\
(0.15)\end{array}$ \\
\hline Zambia & -53.29 & $\begin{array}{l}-13.87 \\
(0.04)\end{array}$ & $\begin{array}{r}-11.32 \\
(0.05)\end{array}$ & 3.26 & -4.39 & $\begin{array}{l}-26.96 \\
(0.16)\end{array}$ \\
\hline Madagascar & -2.91 & $\begin{array}{l}-1.36 \\
(0.03)\end{array}$ & $\begin{array}{l}-20.61 \\
(0.06)\end{array}$ & -2.46 & -2.68 & $\begin{array}{l}24.20 \\
(0.21)\end{array}$ \\
\hline Senegal & -0.50 & $\begin{array}{c}0.45 \\
(0.07)\end{array}$ & $\begin{array}{r}-17.95 \\
(0.06)\end{array}$ & -3.08 & -0.21 & $\begin{array}{l}20.29 \\
(0.22)\end{array}$ \\
\hline Tanzania & -12.37 & $\begin{array}{l}-3.10 \\
(0.04)\end{array}$ & $\begin{array}{l}-25.06 \\
(0.06)\end{array}$ & -2.94 & 0.84 & $\begin{array}{l}17.89 \\
(0.21)\end{array}$ \\
\hline Ethiopia & -28.92 & $\begin{array}{l}-3.99 \\
(0.02)\end{array}$ & $\begin{array}{l}-25.01 \\
(0.06)\end{array}$ & -1.03 & -2.81 & $\begin{array}{c}3.91 \\
(0.24)\end{array}$ \\
\hline Mali & -85.05 & $\begin{array}{c}1.38 \\
(0.08)\end{array}$ & $\begin{array}{l}-38.59 \\
(0.05)\end{array}$ & 10.17 & 6.13 & $\begin{array}{l}-64.14 \\
(0.32)\end{array}$ \\
\hline Burkina Faso & -39.69 & $\begin{array}{r}-16.76 \\
(0.08)\end{array}$ & $\begin{array}{l}-36.47 \\
(0.06) \\
\end{array}$ & 11.93 & -1.35 & $\begin{array}{c}2.97 \\
(0.46) \\
\end{array}$ \\
\hline
\end{tabular}

Source: The BACI database of CEPII. Computations by authors. 
Table 14: Decomposition of Exports Market Share Growth

\begin{tabular}{||l|c|cccc|c||}
\hline \hline Country & $\begin{array}{l}\text { Market } \\
\text { share } \\
\text { growth }\end{array}$ & $\begin{array}{l}\text { Geogra- } \\
\text { phic } \\
\text { demand } \\
\text { effect }\end{array}$ & $\begin{array}{l}\text { Sectoral } \\
\text { demand } \\
\text { effect }\end{array}$ & $\begin{array}{l}\text { Geogra- } \\
\text { phic } \\
\text { adap- } \\
\text { tation }\end{array}$ & $\begin{array}{l}\text { Sectoral } \\
\text { adap- } \\
\text { tation }\end{array}$ & $\begin{array}{l}\text { Competi- } \\
\text { tiveness }\end{array}$ \\
\hline & \multicolumn{7}{|c|}{$1995-1998$} \\
\hline European Union & 3.0 & 3.6 & 0.7 & -0.4 & -0.2 & -0.7 \\
USA & 0.2 & 0.0 & 2.5 & 1.0 & 0.9 & -4.1 \\
Japan & -8.0 & -4.6 & 5.2 & 0.9 & -1.0 & -8.5 \\
Others North & -5.2 & -1.4 & -0.3 & -0.3 & -0.2 & -3.0 \\
China & 15.9 & -8.5 & -1.3 & 0.5 & 0.5 & 24.7 \\
Emerging & 5.2 & -4.5 & -1.8 & 0.2 & 0.2 & 11.1 \\
Non emerg. & 0.8 & 1.0 & -7.4 & -0.4 & 0.2 & 7.5 \\
\hline & \multicolumn{7}{|c|}{$1999-2002$} & & \\
\hline European Union & -1.8 & -2.4 & -0.2 & -1.0 & -0.0 & 1.7 \\
USA & -13.0 & 5.4 & -1.1 & 2.7 & -0.4 & -19.5 \\
Japan & -11.2 & 3.2 & -0.2 & 0.8 & -1.0 & -14.0 \\
Others North & -4.0 & 1.3 & 0.2 & -0.2 & 0.3 & -5.6 \\
China & 37.3 & -2.1 & -4.6 & -0.6 & -0.3 & 44.9 \\
Emerging & 6.1 & 0.5 & -2.7 & 0.1 & 0.5 & 7.7 \\
Non emerg. & 8.7 & -2.0 & 6.6 & -0.0 & 0.6 & 3.4 \\
\hline \hline
\end{tabular}

Source: The BACI database of CEPII. Computations by authors.

Table 15: Decomposition of exports market share growth 1995-2002: intra-EU trade excluded

\begin{tabular}{||l|c|lccc|c||}
\hline \hline Country & $\begin{array}{l}\text { Market } \\
\text { share } \\
\text { growth }\end{array}$ & $\begin{array}{l}\text { Geogra- } \\
\text { phic } \\
\text { demand } \\
\text { effect }\end{array}$ & $\begin{array}{l}\text { Sectoral } \\
\text { demand } \\
\text { effect }\end{array}$ & $\begin{array}{l}\text { Geogra- } \\
\text { phic } \\
\text { adap- } \\
\text { tation }\end{array}$ & $\begin{array}{l}\text { Sectoral } \\
\text { adap- } \\
\text { tation }\end{array}$ & $\begin{array}{l}\text { Competi- } \\
\text { tiveness }\end{array}$ \\
\hline European Union & 0.86 & -1.20 & 1.54 & -0.18 & 0.28 & 0.43 \\
Germany & 12.60 & 0.86 & 2.35 & 0.21 & 0.34 & 8.84 \\
United Kingdom & -16.87 & -2.70 & 4.44 & -0.62 & 0.76 & -18.76 \\
Italy & -8.51 & -1.29 & -4.05 & 0.57 & -1.20 & -2.54 \\
France & -2.60 & -2.47 & 3.59 & -0.93 & 0.67 & -3.45 \\
Belgium & 3.72 & -1.81 & -0.29 & 0.22 & 1.98 & 3.62 \\
Netherlands & -1.34 & -2.50 & 0.42 & -1.04 & 0.04 & 1.74 \\
Sweden & -10.66 & -1.63 & 5.38 & -1.72 & -1.59 & -11.09 \\
Spain & 7.49 & -2.30 & -2.82 & 4.94 & -0.59 & 8.26 \\
Austria & 9.28 & 4.78 & -0.57 & -2.04 & 0.56 & 6.55 \\
Ireland & 70.17 & -1.85 & 10.34 & -1.87 & 2.08 & 61.47 \\
Finland & -0.07 & -3.30 & -0.55 & -0.38 & 0.99 & 3.17 \\
\hline
\end{tabular}


World Trade Competitiveness: A Disaggregated View by Shift-Share Analysis

Table 15: Decomposition of exports market share growth 1995-2002:

intra-EU trade excluded (continued)

\begin{tabular}{|c|c|c|c|c|c|c|}
\hline Country & $\begin{array}{l}\text { Market } \\
\text { share } \\
\text { growth }\end{array}$ & $\begin{array}{l}\text { Geogra- } \\
\text { phic } \\
\text { demand } \\
\text { effect }\end{array}$ & $\begin{array}{l}\text { Sectoral } \\
\text { demand } \\
\text { effect }\end{array}$ & $\begin{array}{l}\text { Geogra- } \\
\text { phic } \\
\text { adap- } \\
\text { tation }\end{array}$ & $\begin{array}{l}\text { Sectoral } \\
\text { adap- } \\
\text { tation }\end{array}$ & $\begin{array}{l}\text { Competi- } \\
\text { tiveness }\end{array}$ \\
\hline Denmark & -3.39 & -3.91 & 0.68 & -1.66 & 0.95 & 0.56 \\
\hline Portugal & -10.29 & -1.93 & -8.82 & 0.14 & 2.80 & -2.47 \\
\hline Greece & -10.59 & -1.83 & -12.89 & -0.82 & 0.89 & 4.05 \\
\hline USA & -12.47 & 5.41 & 2.18 & 6.40 & 0.16 & -26.62 \\
\hline Japan & -18.00 & -0.32 & 6.19 & -1.53 & -2.40 & -19.94 \\
\hline Others North & -8.71 & 0.98 & 0.49 & -2.03 & -0.43 & -7.71 \\
\hline Canada & -9.63 & 6.07 & 0.03 & -3.58 & -0.15 & -12.00 \\
\hline Taiwan & -6.06 & -0.71 & 0.78 & 3.15 & 0.78 & -10.05 \\
\hline Singapore & -9.91 & -5.75 & 8.72 & -2.45 & -2.23 & -8.21 \\
\hline Switzerland & -6.69 & 0.13 & 3.29 & -3.25 & -1.23 & -5.62 \\
\hline Norway & -10.21 & 2.14 & 3.51 & -3.89 & 0.03 & -12.00 \\
\hline Australia & -4.59 & -7.98 & -14.22 & -2.60 & 0.93 & 19.29 \\
\hline Hong Kong & -22.14 & 6.42 & -3.50 & -2.90 & -2.01 & -20.15 \\
\hline Israel & 11.53 & 1.74 & 0.22 & -2.52 & 0.34 & 11.76 \\
\hline New Zealand & -14.27 & -4.54 & -13.25 & -1.12 & -0.96 & 5.60 \\
\hline China & 59.67 & -10.16 & -7.23 & -0.99 & 2.28 & 75.76 \\
\hline Emerging & 12.57 & -3.13 & -4.87 & -0.88 & 1.16 & 20.29 \\
\hline South Korea & 9.09 & -2.57 & -0.17 & 1.92 & 1.55 & 8.36 \\
\hline Malaysia & 3.90 & -7.44 & 3.69 & -0.95 & 0.44 & 8.16 \\
\hline Indonesia & 3.57 & -6.83 & -7.03 & -2.85 & 0.06 & 20.21 \\
\hline Thailand & 11.83 & -5.62 & -4.48 & -1.07 & 1.40 & 21.60 \\
\hline India & 13.84 & -3.59 & -12.68 & -1.41 & 0.53 & 30.98 \\
\hline Poland & 34.35 & 0.48 & -6.43 & -2.52 & 3.73 & 39.09 \\
\hline Turkey & 37.25 & 0.74 & -15.26 & -2.49 & 2.34 & 51.93 \\
\hline Chile & -2.76 & -4.19 & -15.98 & 4.99 & -1.44 & 13.85 \\
\hline Hungary & 73.01 & 1.89 & -2.76 & -3.73 & 6.44 & 71.16 \\
\hline Slovakia & 29.27 & 9.99 & -6.02 & -7.26 & 2.85 & 29.71 \\
\hline Slovenia & 5.11 & 3.12 & 1.13 & -4.27 & 0.62 & 4.50 \\
\hline Viet Nam & 80.27 & -8.03 & -16.00 & 1.13 & 1.18 & 101.99 \\
\hline Egypt & -36.65 & 5.54 & -4.21 & -5.17 & -7.71 & -25.10 \\
\hline Pakistan & 5.72 & -2.16 & -22.55 & 0.81 & -0.64 & 30.27 \\
\hline Ecuador & -21.58 & 1.93 & -11.41 & -6.54 & -0.11 & -5.46 \\
\hline Tunisia & 5.55 & 5.60 & -15.34 & -4.95 & -0.10 & 20.34 \\
\hline
\end{tabular}


Table 15: Decomposition of exports market share growth 1995-2002: intra-EU trade excluded (continued)

\begin{tabular}{|c|c|c|c|c|c|c|}
\hline Country & $\begin{array}{l}\text { Market } \\
\text { share } \\
\text { growth }\end{array}$ & $\begin{array}{l}\text { Geogra- } \\
\text { phic } \\
\text { demand } \\
\text { effect }\end{array}$ & $\begin{array}{l}\text { Sectoral } \\
\text { demand } \\
\text { effect }\end{array}$ & $\begin{array}{l}\text { Geogra- } \\
\text { phic } \\
\text { adap- } \\
\text { tation }\end{array}$ & $\begin{array}{l}\text { Sectoral } \\
\text { adap- } \\
\text { tation }\end{array}$ & $\begin{array}{l}\text { Competi- } \\
\text { tiveness }\end{array}$ \\
\hline Bangladesh & 11.58 & 3.27 & -20.64 & -4.05 & -2.60 & 35.60 \\
\hline Croatia & -18.52 & 4.32 & -4.74 & -4.81 & 0.84 & -14.13 \\
\hline Costa Rica & 21.41 & 7.78 & -18.90 & -2.49 & 12.72 & 22.31 \\
\hline Sri Lanka & 11.91 & 3.01 & -18.96 & -4.61 & -2.28 & 34.74 \\
\hline Lithuania & 17.29 & -2.63 & -11.05 & -2.06 & 3.34 & 29.70 \\
\hline Mauritius & -11.88 & 3.46 & -23.20 & -5.34 & -0.52 & 13.72 \\
\hline Uganda & -42.43 & 2.02 & -35.27 & -9.25 & 3.51 & -3.45 \\
\hline Sudan & 283.24 & 1.32 & -31.22 & 19.12 & 32.07 & 261.96 \\
\hline Mozambique & 176.83 & -1.70 & -23.11 & -1.04 & 6.47 & 196.21 \\
\hline Non emerging & 13.97 & 0.55 & -3.39 & -2.39 & 0.11 & 19.07 \\
\hline Russia & 1.31 & 4.89 & -1.95 & -2.53 & 0.79 & 0.11 \\
\hline Mexico & 71.55 & 5.54 & 4.45 & -3.91 & 0.70 & 64.77 \\
\hline Saudi Arabia & 28.85 & -4.44 & 9.60 & -4.75 & -2.95 & 31.40 \\
\hline Brazil & -2.04 & -4.77 & -14.67 & 2.54 & 1.64 & 13.23 \\
\hline Philippines & 14.01 & -5.15 & 1.22 & -1.08 & 2.44 & 16.57 \\
\hline South Africa & 1.74 & -5.41 & -14.26 & -0.33 & 0.77 & 20.95 \\
\hline Argentina & -10.64 & -7.77 & -13.22 & -0.63 & 0.35 & 10.63 \\
\hline Venezuela & -17.64 & 4.01 & 4.87 & -1.81 & -2.86 & -21.86 \\
\hline Czech Republic & 36.28 & 3.37 & -4.98 & -4.60 & 4.12 & 38.38 \\
\hline Nigeria & -12.13 & 3.95 & 7.23 & -7.00 & -1.24 & -15.07 \\
\hline Algeria & -10.34 & 5.64 & 14.55 & -3.86 & -2.36 & -24.32 \\
\hline Colombia & -15.72 & 4.62 & -12.97 & -1.95 & 2.25 & -7.68 \\
\hline Ukraine & 2.34 & -3.43 & -16.33 & 0.64 & -1.38 & 22.84 \\
\hline Romania & 26.13 & 3.29 & -12.43 & -2.04 & -0.44 & 37.75 \\
\hline Morocco & 1.44 & 5.10 & -18.32 & -4.91 & 0.53 & 19.04 \\
\hline Peru & 12.40 & 3.95 & -17.99 & -4.57 & -3.59 & 34.62 \\
\hline Bulgaria & -11.52 & 3.61 & -12.13 & -1.65 & -2.14 & 0.79 \\
\hline Kazakhstan & 14.67 & -7.54 & -15.25 & 4.51 & 6.46 & 26.49 \\
\hline Côte d'Ivoire & -34.48 & 4.49 & -27.07 & -3.23 & -8.64 & -0.03 \\
\hline Syria & 23.87 & 4.23 & 0.85 & -7.74 & -2.90 & 29.43 \\
\hline Guatemala & -4.15 & 8.98 & -24.08 & -3.90 & 0.51 & 14.33 \\
\hline Uruguay & -35.10 & -10.11 & -17.39 & 0.05 & -0.25 & -7.39 \\
\hline Cameroon & -26.27 & 7.11 & -16.87 & -1.30 & 2.12 & -17.33 \\
\hline Ghana & -54.62 & 0.27 & -24.04 & -1.20 & -4.13 & -25.51 \\
\hline Zimbabwe & -24.71 & -2.44 & -23.63 & -5.41 & -4.10 & 10.88 \\
\hline El Salvador & 22.61 & 10.20 & -19.62 & -3.69 & -0.87 & 36.60 \\
\hline Kenya & -22.57 & -3.30 & -23.97 & -6.16 & 3.33 & 7.54 \\
\hline
\end{tabular}


World Trade Competitiveness: A Disaggregated View by Shift-Share Analysis

Table 15: Decomposition of exports market share growth 1995-2002: intra-EU trade excluded (continued)

\begin{tabular}{||l|l|llll|c||}
\hline \hline Country & $\begin{array}{l}\text { Market } \\
\text { share } \\
\text { growth }\end{array}$ & $\begin{array}{l}\text { Geogra- } \\
\text { phic } \\
\text { demand } \\
\text { effect }\end{array}$ & $\begin{array}{l}\text { Sectoral } \\
\text { demand } \\
\text { effect }\end{array}$ & $\begin{array}{l}\text { Geogra- } \\
\text { phic } \\
\text { adap- } \\
\text { tation }\end{array}$ & $\begin{array}{l}\text { Sectoral } \\
\text { adap- } \\
\text { tation }\end{array}$ & $\begin{array}{l}\text { Competi- } \\
\text { tiveness }\end{array}$ \\
\hline Paraguay & -24.72 & -11.52 & -24.65 & -14.70 & 2.29 & 23.86 \\
Zaire & -21.08 & 7.51 & -8.05 & -0.23 & 1.71 & -22.02 \\
Bolivia & -6.49 & -8.09 & -15.35 & -3.21 & 2.83 & 17.34 \\
Zambia & -53.10 & -12.56 & -11.96 & 2.17 & -4.82 & -25.94 \\
Madagascar & -2.50 & 1.33 & -24.36 & -4.20 & -2.82 & 27.55 \\
Senegal & -0.08 & 2.49 & -20.33 & -3.81 & -0.05 & 21.63 \\
Tanzania & -12.01 & -1.83 & -28.71 & -3.24 & 1.68 & 20.09 \\
Ethiopia & -28.63 & -2.14 & -29.98 & -2.17 & -2.24 & 7.90 \\
Mali & -84.99 & 1.54 & -38.97 & 9.27 & 6.00 & -62.84 \\
Burkina Faso & -39.44 & -18.18 & -37.20 & 13.00 & -2.27 & 5.21 \\
\hline \hline
\end{tabular}

Source: The BACI database of CEPII. Computations by authors.

Table 16: Importing markets' dynamics 1995-2002, (\%)

\begin{tabular}{||l|rr|l|rr||}
\hline \hline Country & $r_{j}$ & $\beta_{j}$ & Country & $r_{j}$ & $\beta_{j}$ \\
\hline European Union & 43.07 & 2.95 & Bangladesh & 5.59 & -21.56 \\
Germany & 31.45 & -9.42 & Croatia & 58.56 & 12.75 \\
United Kingdom & 43.19 & 2.90 & Ecuador & 46.53 & 13.13 \\
France & 40.43 & 0.75 & Costa Rica & 85.19 & 23.92 \\
Italy & 48.81 & 10.30 & Sri Lanka & 70.28 & 12.08 \\
Netherlands & 39.27 & 0.48 & Lithuania & 118.09 & 55.55 \\
Belgium & 55.31 & 14.54 & Mauritius & 15.31 & -21.35 \\
Spain & 70.39 & 31.10 & Sudan & 129.45 & 54.31 \\
Sweden & 29.51 & -9.87 & Mozambique & 51.16 & -17.83 \\
Austria & 40.42 & -4.70 & Uganda & 16.18 & -21.55 \\
Denmark & 36.88 & -4.31 & & & \\
Ireland & 77.20 & 39.30 & Non emerging & 49.59 & 8.12 \\
Portugal & 54.34 & 12.10 & Mexico & 193.24 & 155.24 \\
Finland & 35.08 & -2.96 & Brazil & 18.30 & -20.02 \\
Greece & 55.00 & 11.18 & Russia & 20.52 & -27.20 \\
& & & Philippines & 11.22 & -17.44 \\
USA & 55.48 & 10.60 & Saudi Arabia & 14.01 & -21.60 \\
& & & South Africa & 14.32 & -23.80 \\
Japan & 14.51 & -30.55 & Czech Republic & 91.14 & 33.71 \\
& & & Argentina & -21.77 & -66.32 \\
Others North & 28.70 & -15.50 & Colombia & -1.10 & -29.02 \\
Canada & 36.43 & 9.86 & Ukraine & 31.60 & -33.94 \\
Hong Kong & 20.52 & -38.03 & Venezuela & 59.96 & 23.41 \\
Singapore & 8.73 & -34.68 & Algeria & 23.08 & -15.30 \\
\hline
\end{tabular}


Table 16: Importing markets' dynamics 1995-2002, (\%) (continued)

\begin{tabular}{||l|rr|l|rr||}
\hline \hline Country & $r_{j}$ & $\beta_{j}$ & Country & $r_{j}$ & $\beta_{j}$ \\
\hline Taiwan & 54.05 & -9.26 & Romania & 95.34 & 40.53 \\
Switzerland & 30.22 & -9.75 & Morocco & 40.09 & 11.14 \\
Australia & 33.47 & -6.41 & Peru & 5.95 & -37.91 \\
Norway & 24.08 & -13.27 & Nigeria & 102.73 & 55.37 \\
Israel & 27.07 & -8.63 & Bulgaria & 48.25 & -6.28 \\
New Zealand & 22.09 & -19.48 & Paraguay & -40.48 & -86.67 \\
& & & Guatemala & 77.88 & 35.86 \\
China & 88.32 & 60.13 & Syria & 53.40 & -4.43 \\
& & & Uruguay & -3.18 & -52.97 \\
Emerging & 29.12 & -7.44 & Kazakhstan & 135.42 & 52.01 \\
South Korea & 17.37 & -11.64 & Côte d'Ivoire & -21.64 & -35.77 \\
Malaysia & 14.44 & -17.09 & El Salvador & 71.01 & 25.52 \\
Thailand & -4.13 & -33.30 & Zimbabwe & -27.61 & -83.82 \\
Indonesia & -3.27 & -36.47 & Kenya & 42.97 & -26.34 \\
Turkey & 37.57 & -2.35 & Ghana & -7.60 & -41.39 \\
India & 53.87 & 16.14 & Bolivia & -4.13 & -42.37 \\
Poland & 88.74 & 41.79 & Senegal & 47.16 & 11.79 \\
Hungary & 138.45 & 59.58 & Tanzania & 13.51 & -36.42 \\
Chile & 6.61 & -36.15 & Ethiopia & 32.51 & -14.16 \\
Egypt & 9.01 & -17.10 & Cameroon & 45.53 & 8.76 \\
Slovakia & 86.03 & 17.63 & Zaire & -38.57 & -82.38 \\
Viet Nam & 72.75 & 20.44 & Zambia & 48.37 & -2.41 \\
Slovenia & 46.35 & 4.32 & Mali & -1.32 & -34.95 \\
Pakistan & -3.78 & -43.05 & Madagascar & 28.86 & -0.58 \\
Tunisia & 47.98 & 20.19 & Burkina Faso & -18.98 & -32.68 \\
\hline \hline Source The
\end{tabular}

Source: The BACI database of CEPII. Computations by authors.

Note: $r_{j}$ denotes Imports Growth Rate Dynamic and $\beta_{j}$ Importer-specific Trade Dynamic.

Table 17: Sectoral Dynamics of Trade

\begin{tabular}{||l|ccc|cccc||}
\hline \hline Product group & \multicolumn{3}{|c|}{ Annual Growth Rate } & \multicolumn{3}{l||}{ Sectoral Dynamic (\% per year) } \\
& of World Exports (\%) & & & \\
& $1995-$ & $1995-$ & $1999-$ & $1995-$ & Std. & $1995-$ & $1999-$ \\
& 2002 & 1998 & 2002 & 2002 & Err. & 1998 & 2002 \\
\hline Food and live animals & 2.4 & 1.9 & 2.9 & -5.6 & $(0.06)$ & -5.1 & -3.8 \\
Miscellaneous edible products & 5.2 & 4.4 & 6.1 & -1.9 & $(0.06)$ & -2.5 & -0.4 \\
Fish, crustaceans, molluscs etc. & 3.6 & 3.8 & 3.5 & -3.5 & $(0.05)$ & -2.2 & -3.1 \\
Meat and meat preparations & 2.8 & 0.4 & 5.2 & -4.0 & $(0.06)$ & -5.4 & -0.9 \\
Vegetables and fruit & 4.0 & 5.0 & 3.1 & -4.3 & $(0.05)$ & -2.8 & -4.0 \\
Dairy products and eggs & 2.6 & 2.5 & 2.6 & -5.2 & $(0.06)$ & -5.0 & -3.2 \\
Animal feeds, excl. unmilled cereals & 2.9 & 0.7 & 5.2 & -5.4 & $(0.06)$ & -7.2 & -1.1 \\
Cereals and cereal preparations & -0.6 & -3.2 & 2.0 & -8.1 & $(0.05)$ & -9.7 & -4.9 \\
Live animals & 0.6 & -0.9 & 2.2 & -8.5 & & -8.9 & -4.5 \\
\hline
\end{tabular}


Table 17: Sectoral Dynamics of Trade (continued)

\begin{tabular}{|c|c|c|c|c|c|c|c|}
\hline \multirow[t]{2}{*}{ Product group } & \multicolumn{3}{|c|}{$\begin{array}{l}\text { Annual Growth Rate } \\
\text { of World Exports } \\
(\%)\end{array}$} & \multicolumn{4}{|c|}{ Sectoral Dynamic (\% per year) } \\
\hline & $\begin{array}{l}1995- \\
2002\end{array}$ & $\begin{array}{l}1995- \\
1998\end{array}$ & $\begin{array}{l}1999- \\
2002\end{array}$ & $\begin{array}{l}1995- \\
2002\end{array}$ & $\begin{array}{l}\text { Std. } \\
\text { Err. }\end{array}$ & $\begin{array}{l}1995- \\
1998\end{array}$ & $\begin{array}{l}1999- \\
2002\end{array}$ \\
\hline Coffee, tea, cocoa, spices & 0.3 & 4.2 & -3.5 & -9.9 & $(0.06)$ & -3.8 & -11.0 \\
\hline Sugars, sugar prep. and honey & 0.8 & -1.7 & 3.4 & -10.6 & $(0.06)$ & -9.5 & -6.2 \\
\hline Animal and vegetable oils, fats & 3.8 & 4.2 & 3.4 & -1.8 & $(0.06)$ & -1.4 & -1.9 \\
\hline Beverages & 5.8 & 6.4 & 5.2 & 0.7 & $(0.06)$ & 0.6 & 0.4 \\
\hline Tobacco and tobacco manufactures & 0.6 & 1.0 & 0.3 & -5.9 & $(0.06)$ & -4.5 & -5.9 \\
\hline Crude materials, inedible & 1.0 & -1.0 & 3.2 & -7.4 & $(0.06)$ & -8.2 & -3.9 \\
\hline Oil seeds and oleaginous fruit & 3.7 & 2.7 & 4.7 & -4.6 & $(0.06)$ & -7.3 & -1.9 \\
\hline Metalliferous ores, metal scrap & 3.4 & 1.2 & 5.7 & -5.0 & $(0.05)$ & -6.3 & -2.6 \\
\hline Crude animal and veget. materials & 2.8 & 4.6 & 1.1 & -5.2 & $(0.06)$ & -2.8 & -5.1 \\
\hline Cork and wood & 0.1 & -0.2 & 0.4 & -6.3 & $(0.06)$ & -5.6 & -4.7 \\
\hline Hides, skins and furskins, raw & 0.5 & -6.9 & 8.5 & -6.4 & $(0.08)$ & -13.1 & 3.1 \\
\hline Pulp and waste paper & -0.6 & -5.3 & 4.3 & -7.4 & $(0.06)$ & -11.9 & -1.4 \\
\hline Crude fertilizers, crude minerals & 1.8 & 1.9 & 1.6 & -8.4 & $(0.06)$ & -6.0 & -6.5 \\
\hline Crude rubber, synth. and recycled & -1.1 & -5.8 & 3.9 & -11.6 & $(0.06)$ & -14.4 & -3.1 \\
\hline Textile fibres and their wastes & -2.9 & -6.9 & 1.3 & -15.9 & $(0.06)$ & -14.1 & -8.4 \\
\hline Mineral fuels; lubricants & 8.4 & 2.2 & 15.0 & 2.6 & $(0.05)$ & -5.8 & 11.6 \\
\hline Gas, natural and manufactured & 9.3 & 8.5 & 10.2 & 4.6 & $(0.06)$ & 1.6 & 8.8 \\
\hline Petroleum, petroleum products & 8.6 & 1.0 & 16.7 & 2.9 & $(0.05)$ & -7.2 & 13.4 \\
\hline Electric current & 10.5 & 2.1 & 19.5 & -2.8 & $(0.07)$ & -7.3 & 7.4 \\
\hline Coal, coke and briquettes & 3.7 & 0.9 & 6.6 & -4.6 & $(0.06)$ & -7.3 & -0.1 \\
\hline Animal and vegetable oils, fats & 0.5 & 3.5 & -2.4 & -10.9 & $(0.07)$ & -5.4 & -9.8 \\
\hline Fixed vegetable fats and oils & 1.1 & 5.1 & -2.8 & -10.2 & $(0.06)$ & -3.8 & -10.2 \\
\hline Animal/vegetable fats/oils, processed & -0.6 & -1.1 & -0.1 & -11.8 & $(0.09)$ & -9.9 & -8.3 \\
\hline Animal oils and fats & -2.4 & -2.3 & -2.4 & -15.1 & $(0.12)$ & -11.6 & -9.0 \\
\hline Chemicals and related products & 7.4 & 6.6 & 8.3 & 2.4 & $(0.05)$ & 0.7 & 3.1 \\
\hline Medicinal and pharmaceutical prod. & 15.4 & 14.1 & 16.7 & 11.6 & $(0.05)$ & 8.0 & 12.8 \\
\hline Oils, toilet and cleansing prep. & 8.3 & 8.1 & 8.5 & 3.9 & $(0.06)$ & 2.7 & 4.1 \\
\hline Organic chemicals & 6.7 & 6.0 & 7.5 & 1.6 & $(0.05)$ & -0.8 & 2.0 \\
\hline Chem. materials \& products n.e.s. & 5.7 & 5.7 & 5.6 & 1.0 & $(0.05)$ & 0.6 & 0.9 \\
\hline Plastic manufactures & 6.1 & 6.4 & 5.7 & 0.6 & $(0.06)$ & 0.6 & 0.3 \\
\hline Plastics in primary forms & 5.3 & 4.3 & 6.2 & -0.2 & $(0.05)$ & -1.2 & 0.3 \\
\hline Dyeing, tanning and col. materials & 5.0 & 6.6 & 3.5 & -0.5 & $(0.06)$ & 1.1 & -2.2 \\
\hline Inorganic chemicals & 3.5 & 2.5 & 4.6 & -3.4 & $(0.06)$ & -3.8 & -1.9 \\
\hline
\end{tabular}


Table 17: Sectoral Dynamics of Trade (continued)

\begin{tabular}{|c|c|c|c|c|c|c|c|}
\hline \multirow[t]{2}{*}{ Product group } & \multicolumn{3}{|c|}{$\begin{array}{l}\text { Annual Growth Rate } \\
\text { of World Exports } \\
(\%)\end{array}$} & \multicolumn{4}{|c|}{ Sectoral Dynamic (\% per year) } \\
\hline & $\begin{array}{l}1995- \\
2002\end{array}$ & $\begin{array}{l}1995- \\
1998\end{array}$ & $\begin{array}{l}1999- \\
2002\end{array}$ & $\begin{array}{l}1995- \\
2002\end{array}$ & $\begin{array}{l}\text { Std. } \\
\text { Err. }\end{array}$ & $\begin{array}{l}1995- \\
1998\end{array}$ & $\begin{array}{l}1999- \\
2002\end{array}$ \\
\hline Fertilizers, other than of 27 & -1.4 & -3.1 & 0.3 & -12.9 & $(0.06)$ & -10.2 & -7.4 \\
\hline Manufactured goods & 3.8 & 3.6 & 4.0 & -3.5 & $(0.05)$ & -2.7 & -2.9 \\
\hline Manufactures of metal n.e.s. & 6.3 & 7.5 & 5.1 & -0.1 & $(0.05)$ & 1.4 & -1.5 \\
\hline Rubber manufactures, n.e.s. & 5.6 & 7.8 & 3.4 & -0.1 & $(0.06)$ & 1.6 & -1.7 \\
\hline Non-metallic min. manufactures n.e.s. & 5.4 & 4.8 & 6.0 & -1.3 & $(0.05)$ & -1.7 & -0.6 \\
\hline Paper, paperboard, articles thereof & 3.8 & 3.6 & 3.9 & -2.1 & $(0.05)$ & -2.9 & -0.9 \\
\hline Non-ferrous metals & 3.9 & 3.5 & 4.3 & -2.6 & $(0.05)$ & -2.6 & -1.8 \\
\hline Cork and wood manufactures & 4.8 & 5.7 & 3.9 & -2.9 & $(0.06)$ & -1.3 & -3.1 \\
\hline Leather and dressed furskins & 3.6 & -0.9 & 8.3 & -5.5 & $(0.05)$ & -7.8 & -0.9 \\
\hline Textile yarn etc., n.e.s. & 2.7 & 2.9 & 2.5 & -6.8 & $(0.05)$ & -3.5 & -6.9 \\
\hline Iron and steel & 1.2 & -0.4 & 2.7 & -7.5 & $(0.05)$ & -6.7 & -4.9 \\
\hline Machinery and transp. equipment & 7.0 & 8.7 & 5.2 & 2.1 & $(0.05)$ & 3.5 & 0.1 \\
\hline Telecom equipment etc. & 10.2 & 10.3 & 10.1 & 5.1 & $(0.05)$ & 4.8 & 4.3 \\
\hline Other transport equipment & 8.0 & 14.8 & 1.6 & 3.8 & $(0.05)$ & 9.0 & -3.1 \\
\hline Power generating machinery & 8.1 & 10.6 & 5.6 & 3.4 & $(0.05)$ & 5.2 & 1.0 \\
\hline Office machines and computers & 7.6 & 11.3 & 4.0 & 2.9 & $(0.05)$ & 5.7 & -1.1 \\
\hline Road vehicles & 7.6 & 8.9 & 6.3 & 2.8 & $(0.05)$ & 3.1 & 1.9 \\
\hline Elec. machinery, app. and appliances & 7.1 & 9.0 & 5.2 & 2.3 & $(0.05)$ & 3.9 & -0.5 \\
\hline Gen. industr. machinery \& equipm. & 4.8 & 5.1 & 4.6 & -0.1 & $(0.05)$ & 0.5 & -0.6 \\
\hline Machinery for part. industries & 1.9 & 1.8 & 1.9 & -3.6 & $(0.05)$ & -2.2 & -3.2 \\
\hline Metalworking machinery & 1.6 & 3.2 & 0.1 & -4.2 & $(0.06)$ & -1.0 & -5.5 \\
\hline Misc. manufactured articles & 6.4 & 7.1 & 5.7 & -1.0 & $(0.05)$ & 0.3 & -2.0 \\
\hline Prof., scient. \& contr. instruments & 8.6 & 10.0 & 7.2 & 4.9 & $(0.05)$ & 5.3 & 2.9 \\
\hline Furnit., mattr., cushions etc. & 9.3 & 10.8 & 7.8 & 3.4 & $(0.06)$ & 4.6 & 0.8 \\
\hline Photogr. equip., opt. goods; watches & 4.1 & 4.4 & 3.7 & -0.4 & $(0.05)$ & 0.3 & -1.4 \\
\hline Prefab. buildings; fixtures & 6.9 & 8.2 & 5.6 & -0.4 & $(0.06)$ & 1.3 & -2.5 \\
\hline Misc. manufactured articles n.e.s. & 5.9 & 6.7 & 5.1 & -1.0 & $(0.05)$ & 0.1 & -1.8 \\
\hline Apparel and clothing accessories & 6.2 & 6.8 & 5.5 & -4.5 & $(0.05)$ & -1.7 & -5.2 \\
\hline Travel goods, handbags etc. & 4.9 & 4.1 & 5.7 & -7.8 & $(0.07)$ & -4.9 & -6.8 \\
\hline Footwear & 4.9 & 4.0 & 5.9 & -8.1 & $(0.06)$ & -5.6 & -6.6 \\
\hline Other commodities & 0.3 & 7.4 & -6.4 & -8.3 & $(0.07)$ & -3.9 & -13.4 \\
\hline Gold, non-monetary & 0.3 & 7.5 & -6.5 & -8.3 & $(0.06)$ & -3.8 & -13.4 \\
\hline Coin, not being legal tender & -6.4 & -20.8 & 10.7 & -20.5 & $(0.47)$ & -30.6 & -7.8 \\
\hline
\end{tabular}

Source: The BACI database of CEPII. Computations by authors. 
World Trade Competitiveness: A Disaggregated View by Shift-Share Analysis

\section{LIST OF WORKING PAPERS RELEASED BY CEPII ${ }^{1}$}

No

Title

2005-22 Chômage et réformes du marché du travail au Japon

2005-21 Profitability of Foreign and Domestic Banks in Central and Eastern Europe: Does the Mode of Entry Matter?

2005-20 ECB Governance in an Enlarged Eurozone

2005-19 What Are EU Trade Preferences Worth for SubSaharan Africa and Other Developing Countries?

2005-18 Binding Overhang and Tariff-Cutting Formulas

2005-17 International Trade and Income Distribution: Reconsidering the Evidence

2005-16 China and the Relationship between the Oil Price and the Dollar

2005-15 Consequences of Alternative Formulas for Agricultural Tariff Cuts

2005-14 Is Erosion of Tariff Preferences a Serious Concern?

2005-13 The Consequences of Agricultural Trade Liberalization for Developing Countries: Distinguishing Between Genuine Benefits and False Hopes

2005-12 From Bound Duties to Actual Protection: Industrial Liberalisation in the Doha Round

2005-11 Impact de l'ouverture financière sur les inégalités internes dans les pays émergents
Authors

E. Dourille-Feer

O. Havrylchyk \&

E. Jurzyk

A. Bénassy-Quéré \&

E. Turkisch

F. Candau \& S. Jean

M.H. Bchir, S. Jean \&

D. Laborde

I. Bensidoun, S. Jean \&

A. Sztulman

A. Bénassy-Quéré, V. Mignon \& A. Penot

S. Jean, D. Laborde \& W. Martin

A. Bouët, L. Fontagné \& S. Jean

J.C. Bureau, S. Jean

A. Matthews

M.H. Bchir, L. Fontagné \& S. Jean

A. Bénassy-Quéré \& V. Salins

\footnotetext{
${ }^{1}$ Working papers are circulated free of charge as far as stocks are available; thank you to send your request to CEPII, Sylvie Hurion, 9, rue Georges-Pitard, 75015 Paris, or by fax : (33) 0153685504 or by e-mail sylvie.hurion@ @ cepii.fr. Also available on: \www.cepii.fr. Working papers with * are out of print. They can nevertheless be consulted and downloaded from this website.

${ }^{1}$ Les documents de travail sont diffusés gratuitement sur demande dans la mesure des stocks disponibles. Merci d'adresser votre demande au CEPII, Sylvie Hurion, 9, rue Georges-Pitard, 75015 Paris, ou par fax : (33) 0153685504 ou par e-mail_sylvie.hurion@ @ cepii.fr. Egalement disponibles sur : ॥www.cepii.fr. Les documents de travail comportant* sont épuisés. Ils sont toutefois consultable sur le web CEPII.
} 
2005-10 Disentangling Horizontal and Vertical Intra-Industry Trade

2005-09 China's Integration in East Asia: Production Sharing, FDI \& High-Tech Trade

2005-08 Tax Competition and Public Input

2005-07 Trade Liberalisation, Growth and Poverty in Senegal: A Dynamic Microsimulation CGE Model Analysis

2005-06 Migration, Trade and Wages

2005-05 Institutional Determinants of Foreign Investment

2005-04 L'économie indienne : changements structurels et perspectives à long terme

2005-03 Programme de travail du CEPII pour 2005

2005-02 Market Access in Global and Regional Trade

2005-01 Real Equilibrium Exchange Rate in China

2004-22 A Consistent, ad-valorem Equivalent Measure of Applied Protection Across the World: The MacMapHS6 Database

2004-21 IMF in Theory: Sovereign Debts, Judicialisation and Multilateralism

2004-20 The Impact of Multilateral Liberalisation on European Regions: a CGE Assessment

2004-19 La compétitivité de l'agriculture et des industries agroalimentaires dans le Mercosur et l'Union européenne dans une perspective de libéralisation commerciale

2004-18 Multilateral Agricultural Trade Liberalization: The Contrasting Fortunes of Developinc Countries in the Doha Round

2004-17 UK in or UK out? A Common Cycle Analysis between the UK and the Euro Zone

2004-16 Regionalism and the Regionalisation of International Trade
L. Fontagné,

M. Freudenberg \&

G. Gaulier

G. Gaulier, F. Lemoine D. Ünal-Kesenci

A. Bénassy-Quéré, N. Gobalraja \&

A. Trannoy

N. Annabi, F. Cissé, J. Cockburn \&

B. Decaluwé

A. Hijzen \& P. Wright

A. Bénassy-Quéré, M. Coupet \& T. Mayer

S. Chauvin \& F. Lemoine

T. Mayer \& S. Zignago

V. Coudert \&

C. Couharde

A. Bouët, Y. Decreux, L. Fontagné, S. Jean \& D. Laborde J. Sgard

S. Jean \& D. Laborde

N. Mulder, A. Vialou, B. David, M. Rodriguez \& M. Castilho

A. Bouët, J.C. Bureau, Y. Decreux \& S. Jean

J. Garnier

G. Gaulier, S. Jean \& D. Ünal-Kesenci 
2004-15 The Stock-Flow Approach to the Real Exchange Rate of CEE Transition Economies

2004-14 Vieillissement démographique, épargne et retraite : une analyse à l'aide d'un modèle d'équilibre général à agents hétérogènes

2004-13 Burden Sharing and Exchange-Rate Misalignments within the Group of Twenty

2004-12 Regulation and Wage Premia

2004-11 The Efficiency of Fiscal Policies: a Survey of the Literature

2004-10 La réforme du marché du travail en Allemagne : les enseignements d'une maquette

2004-09 Typologie et équivalence des systèmes de retraites

2004-08 South - South Trade: Geography Matters

2004-07 Current Accounts Dynamics in New EU Members: Sustainability and Policy Issues

2004-06 Incertitude radicale et choix du modèle

2004-05 Does Exchange Rate Regime Explain Differences in Economic Results for Asian Countries?

2004-04 Trade in the Triad: How Easy is the Access to Large Markets?

2004-03 Programme de travail du CEPII pour 2004

2004-02 Technology Differences, Institutions and Economic Growth: a Conditional Conditional Convergence

2004-01 Croissance et régimes d'investissement

2003-22 A New Look at the Feldstein-Horioka Puzzle using a Integrated Panel

2003-21 Trade Linkages and Exchange Rates in Asia :The Role of China
B. Egert,

A. Lahrèche-Révil \&

K. Lommatzsch

C. Bac \& J. Chateau

A. Bénassy-Quéré,

P. Duran-Vigneron,

A. Lahrèche-Révil \&

V. Mignon

S. Jean \& G. Nicoletti

S. Capet

S. Capet

P. Villa

S. Coulibaly \&

L. Fontagné

P. Zanghieri

P. Villa

V. Coudert \&

M. Dubert

L. Fontagné, T. Mayer \& S. Zignago

H. Boulhol

P. Villa

A. Banerjee

P. Zanghieri

A. Bénassy-Quéré \&

A. Lahrèche-Révil 


\section{CEPII \\ DOCUMENTS DE TRAVAIL / WORKING PAPERS}

Si vous souhaitez recevoir des Documents de travail, merci de remplir le coupon-réponse ci-joint et de le retourner à :

Should you wish to receive copies of the CEPII's Working papers, just fill the reply card and return it to:

Sylvie HURION - Publications

CEPII - 9, rue Georges-Pitard - 75740 Paris - Fax : (33) 1.53.68.55.04

sylvie.hurion@cepii.fr

M./Mme / Mr./Mrs

Nom-Prénom / Name-First name

Titre / Title .

Service / Department.....

Organisme / Organisation

Adresse / Address.

Ville \& CP / City \& post code.

Pays / Country. Tél.

Your e-mail

Désire recevoir les Document de travail du CEPII $n^{\circ}$ :

Wish to receive the CEPII's Working Papers No:

Souhaite être placé sur la liste de diffusion permanente (pour les bibliothèques)

Wish to be placed on the standing mailing list (for Libraries). 